\title{
High-Temperature Borehole Instrumentation
}

Bert R. Dennis

Steven F'. Koczan

Evon L. Stephani

\section{JISCLAIMER}

This report was prepared as an account of work sponsored by an agency of the United States Government. Neither the United States Government nor any agency thereof, nor any of their employees, makes any warranty, express or implied, or assumes any legal liability or responsibility for the accuracy, completeness, or usefulness of any information, apparatus, product, or process disclosed, or represents that its use would not infringe privately owned rights. Reference herein to any specific commercial product, process, or service by trade name, trademark, manufacturer, or otherwise does not necessarily constitute or imply its endorsement, recommendation, or favoring by the United States Government or any agency thereof. The views and opinions of authors expressed herein do not necessarily state or reflect those of the United States Government or any agency thereof.
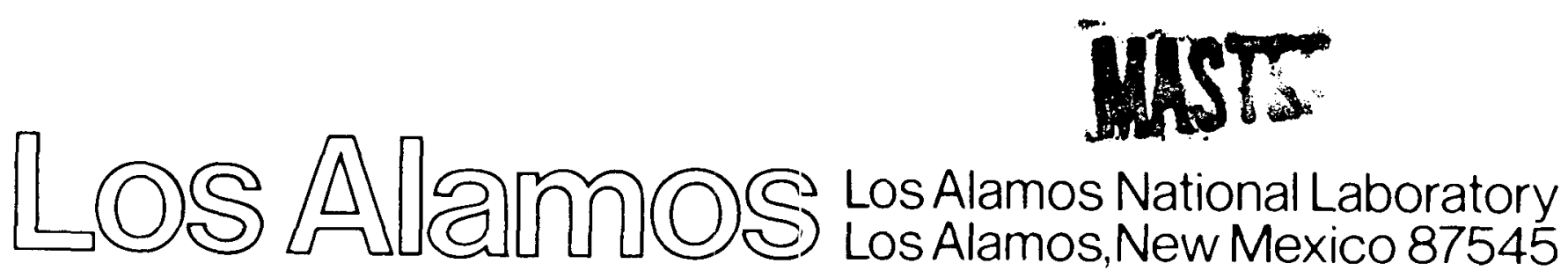


\section{DISCLAIMER}

This report was prepared as an account of work sponsored by an agency of the United States Government. Neither the United States Government nor any agency Thereof, nor any of their employees, makes any warranty, express or implied, or assumes any legal liability or responsibility for the accuracy, completeness, or usefulness of any information, apparatus, product, or process disclosed, or represents that its use would not infringe privately owned rights. Reference herein to any specific commercial product, process, or service by trade name, trademark, manufacturer, or otherwise does not necessarily constitute or imply its endorsement, recommendation, or favoring by the United States Government or any agency thereof. The views and opinions of authors expressed herein do not necessarily state or reflect those of the United States Government or any agency thereof. 


\section{DISCLAIMER}

Portions of this document may be illegible in electronic image products. Images are produced from the best available original document. 


\section{DISCLAIMER}

Portions of this document may be illegible in electronic image products. Images are produced from the best available original document. 


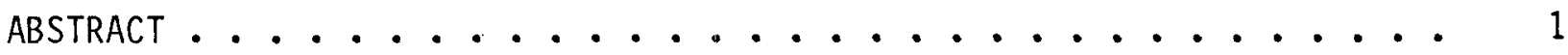

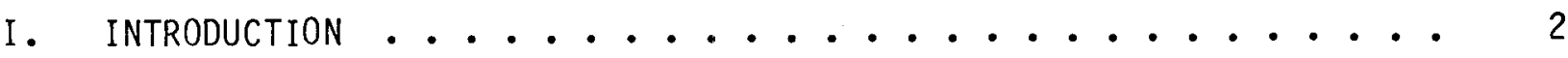

II. SPECIAL FACILITIES ....................... 5

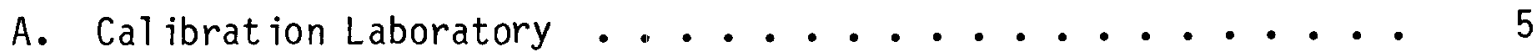

B. Dry Thermal Test Oven ................... 5

C. Armored Cable Test Facility ................. 6

D. Instrument Sonde Test Facility .............. 6

III. DOWNHOLE EQUIPMENT DESIGN AND FABRICATION . . . . . . 8

A. Computer-Aided Design $(C A D) \ldots \ldots \ldots$

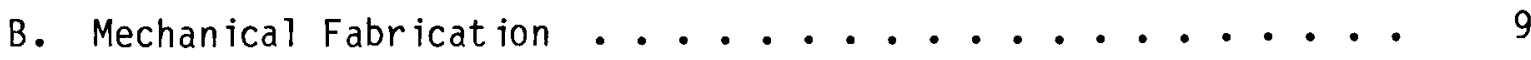

C. Downhole Sonde Assembly and Test Laboratory ....... 11

D. Electronic Design and Computer Facilities ....... 12

E. Geothermal Wellbore Logging Equipment ........ 13

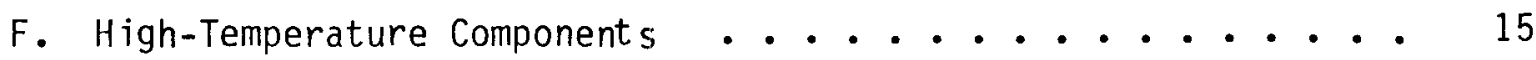

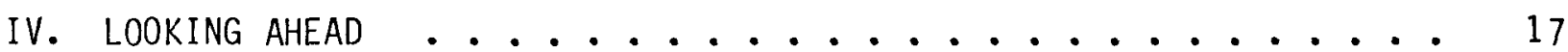

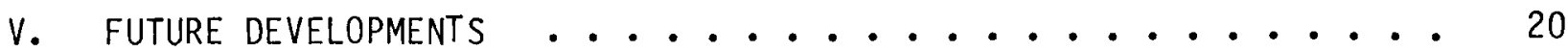

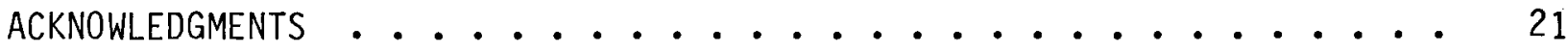

BIBLIOGRAPHY $\ldots \ldots \ldots \ldots \ldots 2_{22}$

APPENDIX: HIGH-TEMPERATURE BOREHOLE INSTRUMENTS ........ 28

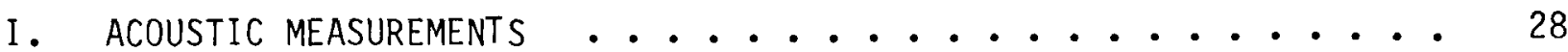

II. DOWNHOLE EXPLOSIVE DEVICES .................. 29

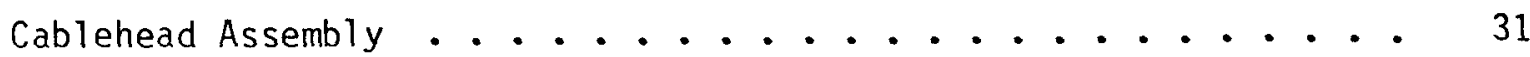

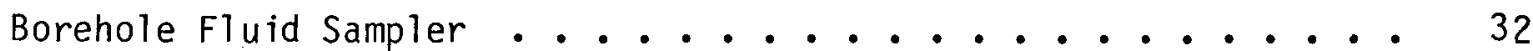

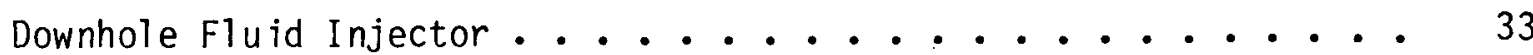

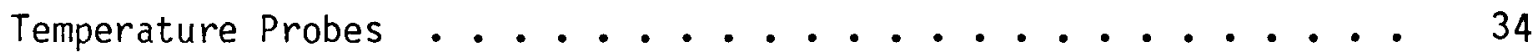

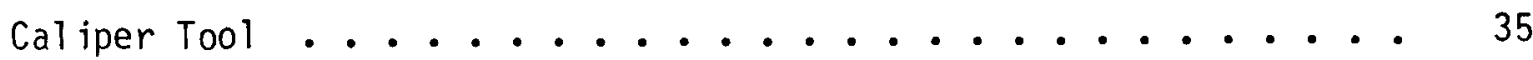

Downhole Injector and Ganma-Ray Detector ......... 36

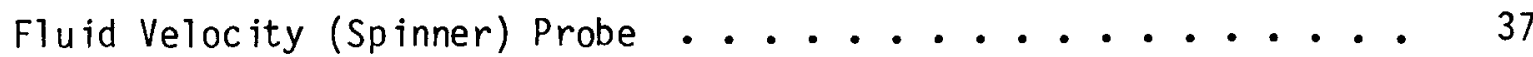

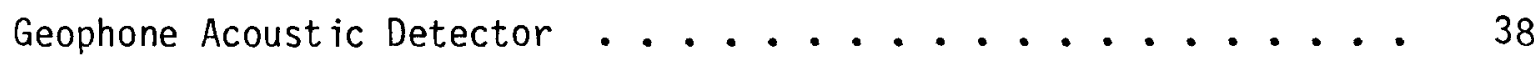

Crosswell Acoust ic Transceiver - Transmitter ........ 39

Crosswell Acoustic Transceiver - Receiver ......... 40

Borehole Acoustic Televiewer .............. 41 
Acoustic Source Detonator ............... . . 42

Sl iml ine Detonator Tool and String Shot ........... 43

Drill Pipe Severing Device . . . . . . . . . . . . 44

Explosive Fracture Initiation Tool . . . . . . . . . . 45

Explosive Sidetracking Tool ................... 46 
HIGH-TEMPERATURE BOREHOLE INSTRUMENTATION

by

Bert R. Dennis, Steven P. Koczan, and Evon L. Stephani

\section{ABSTRACT}

A new method of extracting natural heat from the earth's crust was invented at the Los Alamos National Laboratory in 1970. It uses fluid pressures (hydraulic fracturing) to produce cracks that connect two boreholes drilled into hot rock formations of low initial permeability. Pressurized water is then circulated through this connected underground loop to extract heat from the rock and bring it to the surface.

The creation of the fracture reservoir began with drilling boreholes deep within the Precambrian basement rock at the Fenton $\mathrm{Hill}$ Test Site. Hydraulic fracturing, flow testing, and well-completion operations required unique wellbore measurements using downhole instrumentation systems that would survive the very high borehole temperatures, $320^{\circ} \mathrm{C}\left(610^{\circ} \mathrm{F}\right)$. These instruments were not available in the oil and gas industrial complex, so the Los Alamos National Laboratory initiated an intense program upgrading existing technology where appl icable, subcontracting materials and equipment development to industrial manufacturers, and using the Laboratory resources to develop the necessary downhole instruments to meet programmat ic schedules. 


\section{INTRODUCTION}

The world's first hot dry rock (HDR) energy system was completed in 1977 in granitic rock at a depth of $2590 \mathrm{~m}(8500 \mathrm{ft})$, where the rock temperature is about $185^{\circ} \mathrm{C}\left(365^{\circ} \mathrm{F}\right)$. This Phase I (research) system was located at Fenton $\mathrm{Hill}$ in the Jemez Mountains of northern New Mexico. It was enlarged in 1979 and has operated for a total time of more than a year as a recirculating, pressurized-water, heat-extraction loop. Its longest continuous run produced rates up to $5 \mathrm{MW}$ thermal; some of that heat was used to generate electricity in a small (60-kVA) binary cycle power plant. Water qual ity remained good at less than $2000 \mathrm{ppm}$ of dissolved solids. The rate of water loss decreased with time to less than $8 \%$ of the flow rate through the system, and operation was essentially trouble free. Because of thermal contraction of the rock from which heat was extracted, the subterranean fracture system increased in volume by about $25 \%$ during the 9-month run, with a proportionate increase in effective heat-transfer area. No scaling or corrosion was observed in carbon steel surface equipment, and there were no detectable environmental effects from system operation.

The Phase I HDR system at Fenton Hill demonstrated the technical feasibility and environmental acceptability of extracting useful heat from hot dry rock in the earth's crust and of using that heat to generate electricity. This system, however, is too small and too 1 imited in temperature and rate of heat production to represent a useful energy supply for a commercial-scale power plant or to demonstrate the costs and economics of such a commercial system. For that reason, a larger, deeper, hotter Phase II system is now under construction at the same site.

Drilling, well-completion, hydraulic-fracturing, and flow-testing operations at Fenton $\mathrm{Hill}$ impose requirements on equipment and materials that are not usually encountered in the oil and gas industry or in most other geothermal operations. These demands result from the high temperatures reached [above $320^{\circ} \mathrm{C}\left(610^{\circ} \mathrm{F}\right)$ in the Phase II system], the high fracturing pressures required in crystall ine rock at depths of 3658 to $4267 \mathrm{~m}(12,000$ to $14,000 \mathrm{ft})$, the hardness and abrasiveness of the crystalline rock penetrated, the need for precise control of both azimuth and inclination during directional drilling, and the unconventional and developmental nature of the 
downhole experiments conducted. To meet these special needs, it has been necessary to modify, improve, or redesign many equipment items or to invent new ones. Much of this innovative work has been done independently at Los Alamos. More has been done in cooperation with industrial manufacturers and other laboratories or by subcontract to them.

The Phase II engineering system under construction at Fenton $\mathrm{Hill}$ is much larger, deeper, and hotter than the Fhase I research system. One borehole (EE-2) was drilled to a depth of 475? $\mathrm{m}(15,000 \mathrm{ft})$ of which about $3960 \mathrm{~m}$ $(13,000 \mathrm{ft})$ is in Precambrian granitic rock. Starting at a depth of $2920 \mathrm{~m}$ (9600 ft), the borehole was inclined up to $35^{\circ}$ from vertical. The bottom-hole temperature is $320^{\circ} \mathrm{C}\left(610^{\circ} \mathrm{F}\right)$. The second borehole $(E E-3)$ was drilled to a depth of $4236 \mathrm{~m}(13,900 \mathrm{ft})$. The inclined portion of EE-3 is positioned directly over the EE-2 wellbore with a vertical separation of $450 \mathrm{~m}(1500 \mathrm{ft})$ between them. The two wellbores will be connected by a series of hydraulic-induced fractures, thereby creating an extremely large reservoir of hot rock. Upon completion, this engineering extraction system will produce enough heat to represent a useful energy source and demonstrate the costs of extracting thermal energy from the naturally heated rock beneath the earth's crust (Fig. 1).

Many geophysical measurements were required to develop the HDR research and engineering systems. Downhole instruments that would operate continuously in the severe geothermal environment were necessary to map the hydraulic-produced fractures and to characterize the physical and chemical nature of the reservoirs. Other downhole tools were required for wellbore diagnostics during drilling and well-completion operations. Some of this equipment developed by the petroleum industry could be modified and upgraded for work in hot dry rock. Most of it, however, would not survive when exposed to the extreme conditions of the wells at Fenton Hill with temperatures and pressures exceeding those encountered ir $0 i 1$ and gas exploration.

Successful performance of the instrumentation equipment used to survey the EE-2 and EE-3 wellbores depends upon the capacity of the sensors, instrument sonde, cablehead, and arnored logging cable to work in this high-temperature environment. Many components and materials required in the downhole instrument packages were developed in private industry under contract to the Los Alamos National Laboratory. Research in materials, equipment, and 
instrument development is coordinated with the needs in the other DOE geothermal programs to produce hardware of greatest transprogrammatic ut il ity and to obviate duplication.

It is important to understand that the downhole instrumentation used to characterize the hydraulic fractures and assess the HDR reservoirs must be capable of sustained residence in the geothermal environment. The research

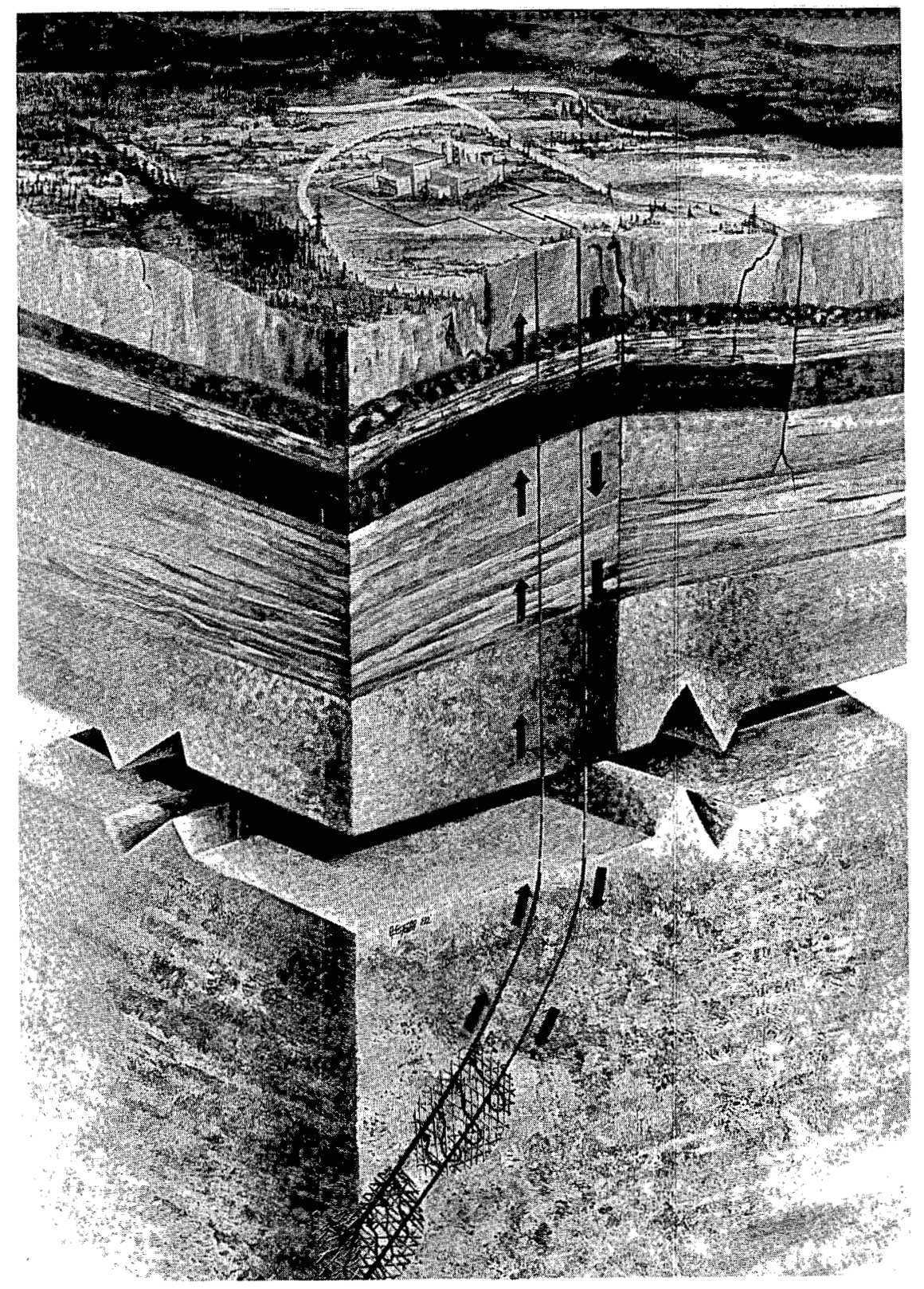

Fig. 1.

Hot dry rock energy extraction system. 
includes sophisticated techniques for geophysical measurement, data acquisition, and subsequent analys is. A wide spectrum of high-temperature equipment for geothermal research is continually being developed.

\section{SPECIAL FACILITIES}

Staff offices, computers, laboratories, and unique testing facilities equipped to support the research and development activities for the HDR Program are centered at Technical Area $33(T A-33)$ in the main Laboratory complex. The Fenton Hill Test Site (TA-57) is located 35 miles west of this support facility in the Jemez Mountains. The equipment is designed, fabricated, and tested at the TA-33 complex before it is taken to TA-57 for field assembly and operation. Outstanding facilities at both sites support the complete capability to develop unique, high-temperature geothermal tools and instruments.

\section{A. Cal ibration Laboratory}

A cal ibration laboratory with computer control and data acquisition houses all equipment necessary to cal ibrate the sensors used in the downhole instrument sondes over an anticipated temperature range from $0^{\circ} \mathrm{C}$ to $320^{\circ} \mathrm{C}$ $\left(610^{\circ} \mathrm{F}\right)$ (Fig. 2). Meticulous cal ibration procedures are carefully performed to ensure dependable measurements over $6000 \mathrm{~m}(20,000 \mathrm{ft})$ of armored logging cable.

\section{B. Dry Thermal Test Oven}

A National $K$ Works environmental muffled oven, Model 65-156, is used to test thermal protection systems in the downhole sonde subassemblies. This oven will accept a sonde or subassembly up to $3.6 \mathrm{~m}$ (12 ft) long and $152 \mathrm{~mm}$ (6 in.) diameter weighing up to $1200 \mathrm{lb}(544.3 \mathrm{~kg})(\mathrm{Fig} .3)$. The oven has a maximum operating temperature of $500^{\circ} \mathrm{C}\left(932^{\circ} \mathrm{F}\right)$ and uses a programmed controller. The thermal protection system used in the downhole sonde may include the pressure housing, dewar, heat sinks, heat pipes, and the electronic circuitry. Thermal simulation of the geothermal borehole environment provides a temperature-time history that is used to model the thermal protection systems to predict optimum size for the various downhole instrument systems. 


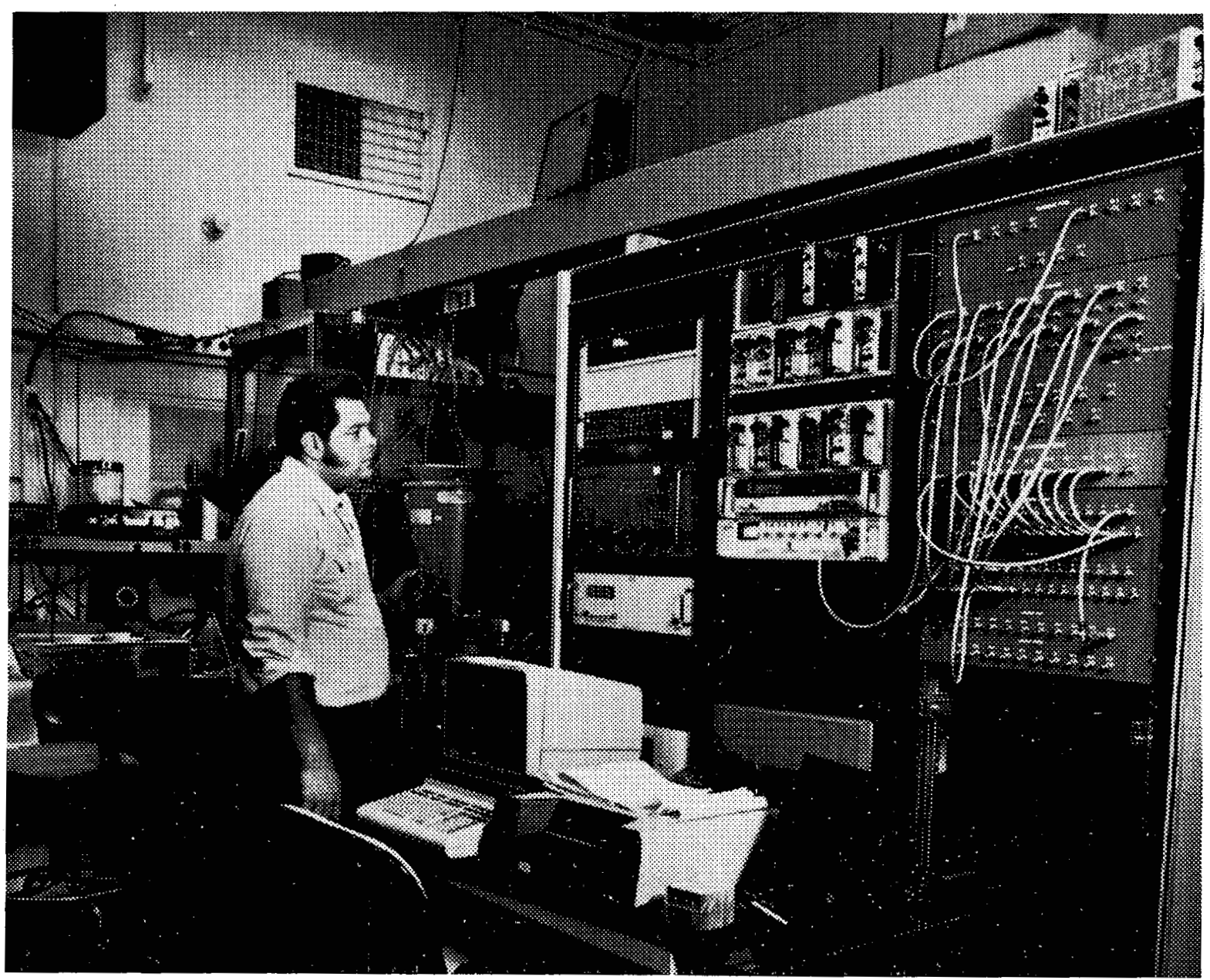

Fig. 2.

Cal ibration laboratory for high-temperature transducers.

\section{Armored Cable Test Facil ity}

The armored cable test facil ity comprises a $6-\mathrm{m}-1$ ong $(20-\mathrm{ft}), 31.75-\mathrm{mm}$ (1-1/4-in.) horizontal autoclave with the necessary heaters, sensors, valves, and plumbing to allow the temperature and pressure to be controlled remotely from an adjacent central control room. This autoclave is designed for operating 1 imits of $350^{\circ} \mathrm{C}\left(662^{\circ} \mathrm{F}\right)$ at $17.24 \mathrm{MPa}(2500 \mathrm{psi})$ using fluids that simulate geothermal brines. Primarily, the system is used to test armored well-logging cables in geothermal environment under constant stat ic stress.

D. Instrument Sonde Test Facil ity

An Instrument Sonde Test Facility (ISTF) has been designed and constructed to check out entire downhole systems and devices that are used in 


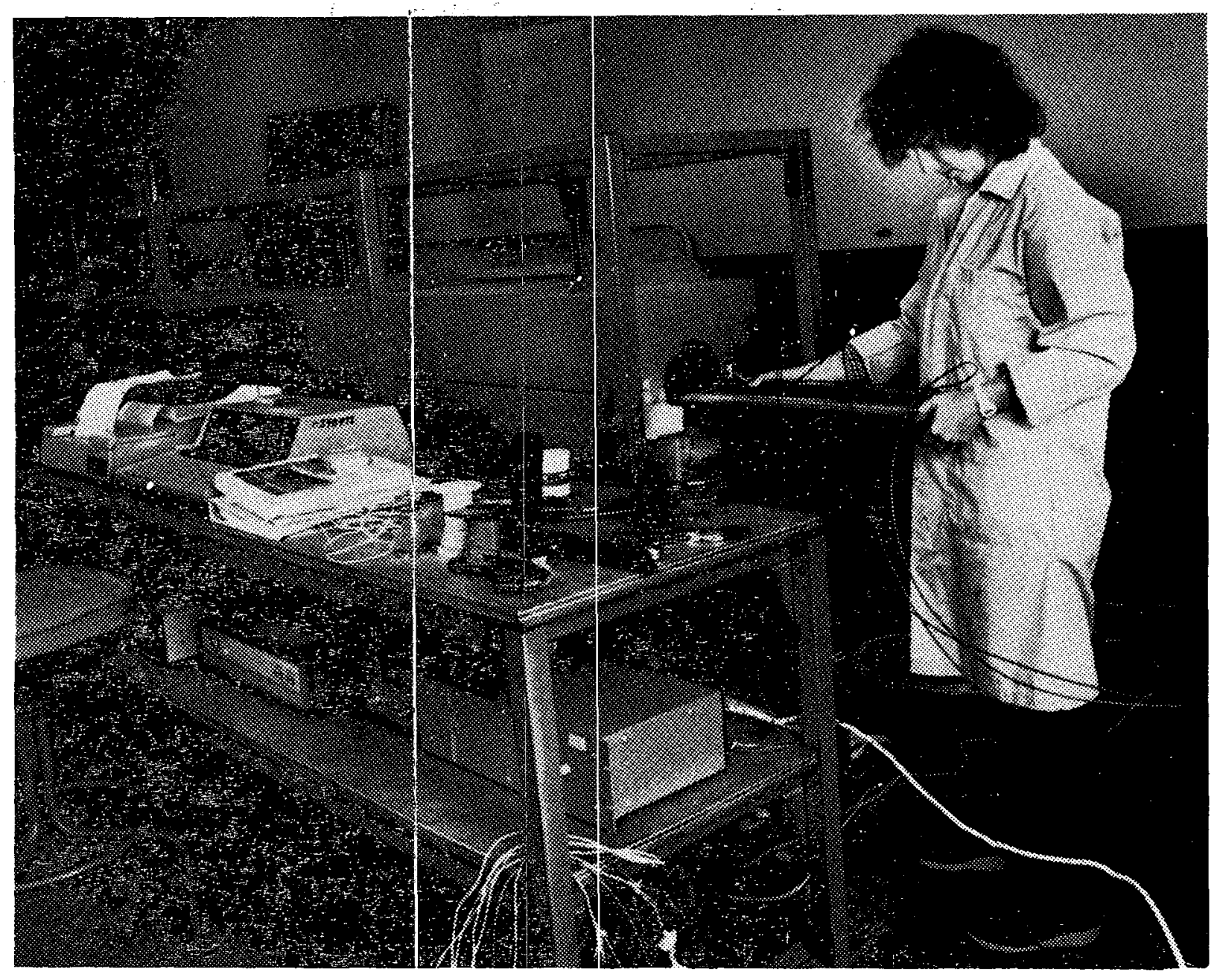

$\mathrm{Figl} .3$.

Dry thermal test oven.

drilling and logging deep geothermal wellbores. The test chamber is designed to accept well-logging tools up to $15 \mathrm{z} \mathrm{mm}$ (6 in.) diameter and $8.5 \mathrm{~m}$ (28 ft) long. The autoclave is designed for temperatures up to $275^{\circ} \mathrm{C}\left(527^{\circ} \mathrm{F}\right)$ with fluid pressures (water) up to $41.4 \mathrm{MPa}$ (6000 psi). Higher temperatures can be achieved at lower fluid pressures. A 7-conductor feedthru allows monitoring the downhole tool under test conditions. The workover tower contains overhead cranes to handle the downhole tools, and the instrument control trailer has a computer control and data acquisition system. Smaller autoclaves are available to test components and subassemblies such as cableheads and related seals and connectors, detonator housing, motor housings, etc. (Fig. 4). 


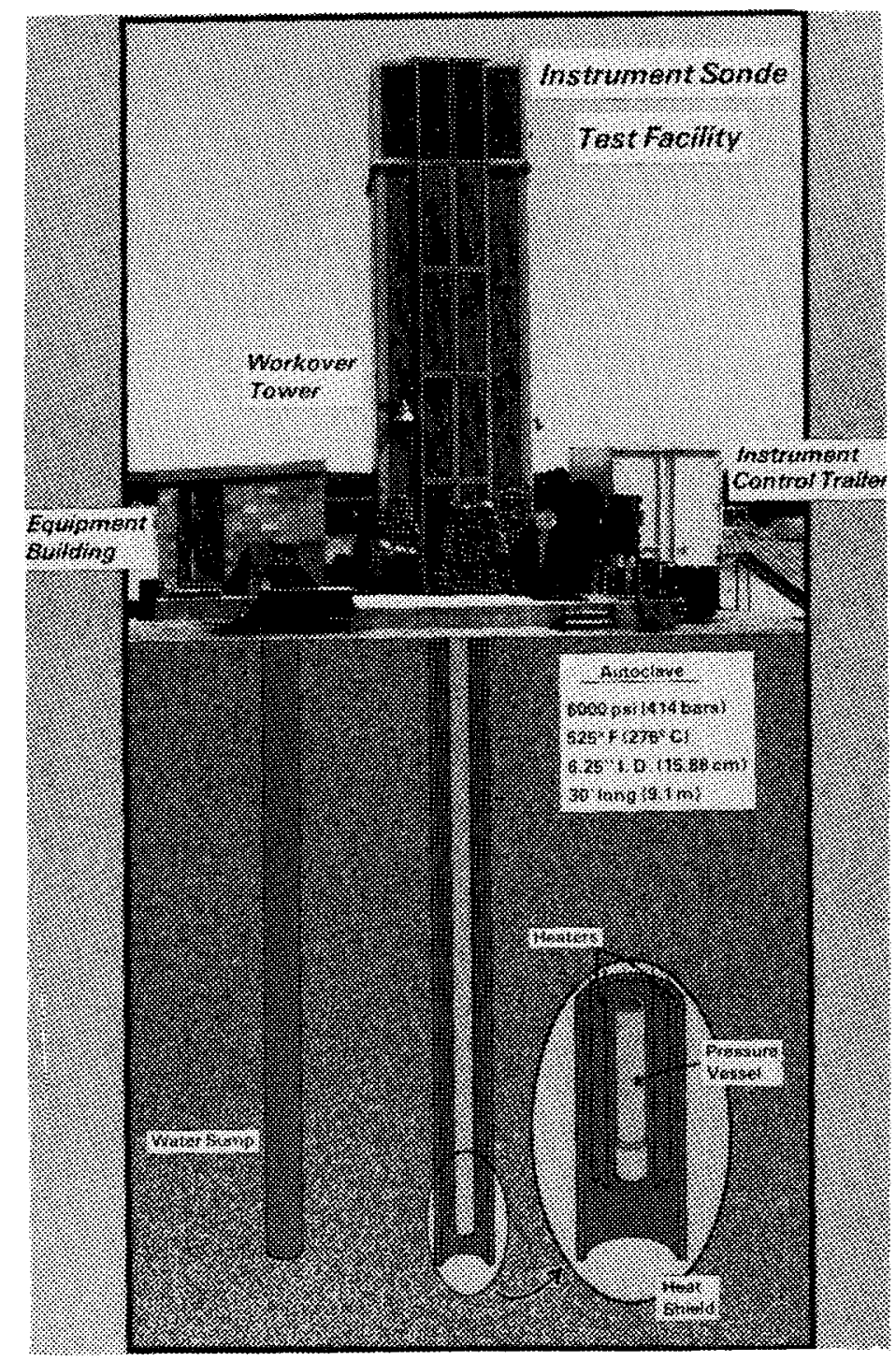

Fig. 4 .

Instrument sonde test facil ity.

\section{DOWNHOLE EQUIPMENT DESIGN AND FABRICATION}

\section{A. Computer-Aided Design (CAD)}

The mechanical and electrical design and drafting for each downhole instrument system leading to shop-ready fabrication drawings are completely carried out on CAD workstations. The four CAD stations were procured from McAuto (McDonnell Douglas Automation Company) and utilize a large array of Unigraphics Software Programs, which are stored in a central processing unit (VAX 11/780) (Fig. 5). 


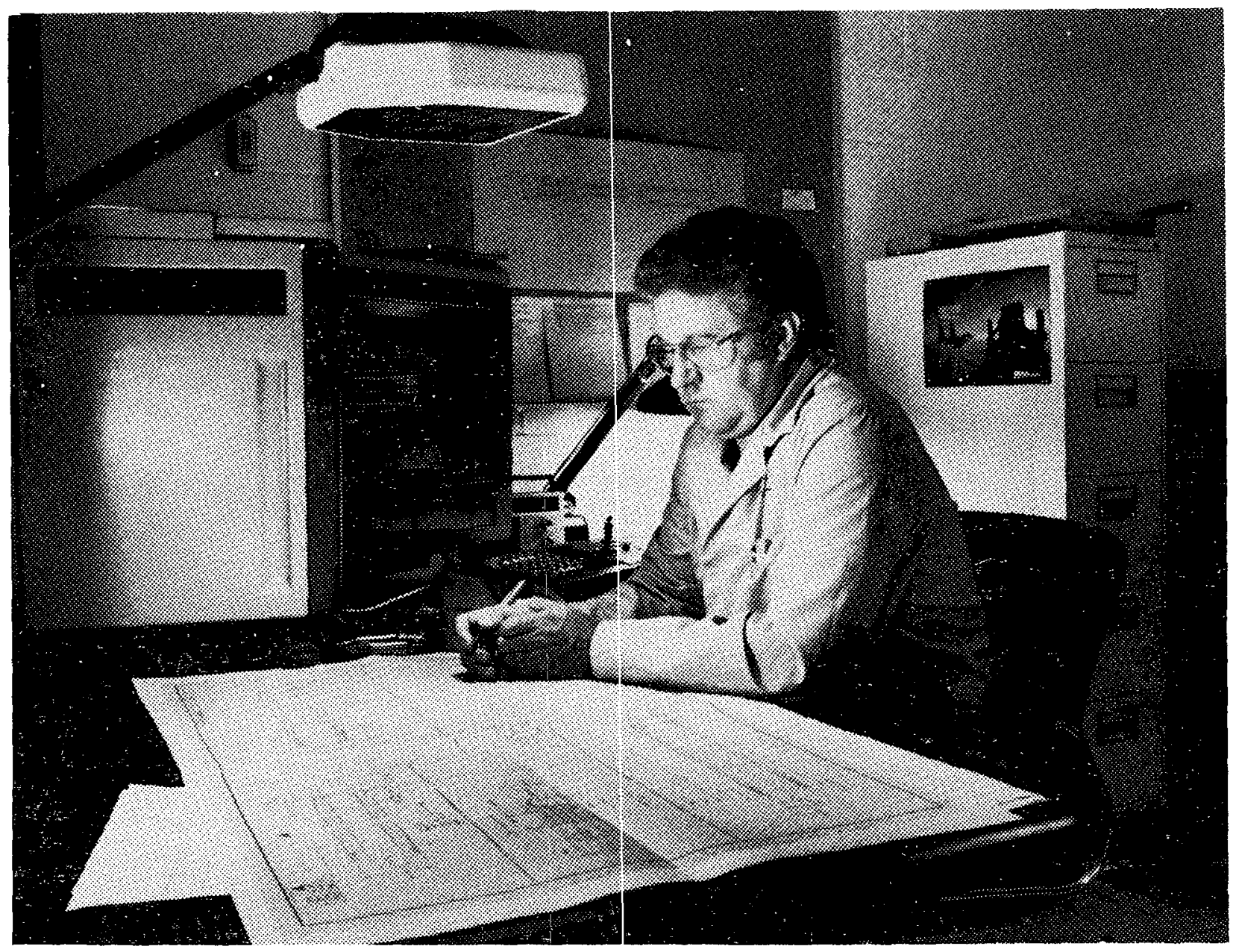

Fig. 5 .

CAD workstation.

The CAD system. efficiently uses computer power for design and drafting. This has allowed for greater efficiency in design of advanced geothermal tools and instruments and has provided a time-saving capability to incorporate modifications into the prototype systems developed at Los Alamos.

\section{B. Mechanical Fabrication}

A machine shop facility at $T A-33$ is staffed with professional machinists who are skilled in the fabrication techniques required to manufacture downhole instrument components and sondes. They also participate in the assembly and testing of the tools and instruments and have assisted in the field deployment. This involvement in every phase of equipment development has produced valuable design modifications that simplify machining operations and 
improve assembly and disassembly procedures, while maintaining sonde integrity under the severe borehole cond itions.

The shop facility is fully equipped with standard machine tools with an expanded complement that includes a Lehman engire lathe with a 227-mm-diam (9-in.) hollow spindle double chuck with a 3.05-m (10-ft) span between centers, a 406-mm (16-in.) Monarch engine lathe, a 914-mm (36-in.) swing radius Cincinnati Brichford radial arm drill press, and a Hobart TIG welding machine (Fig. 6).

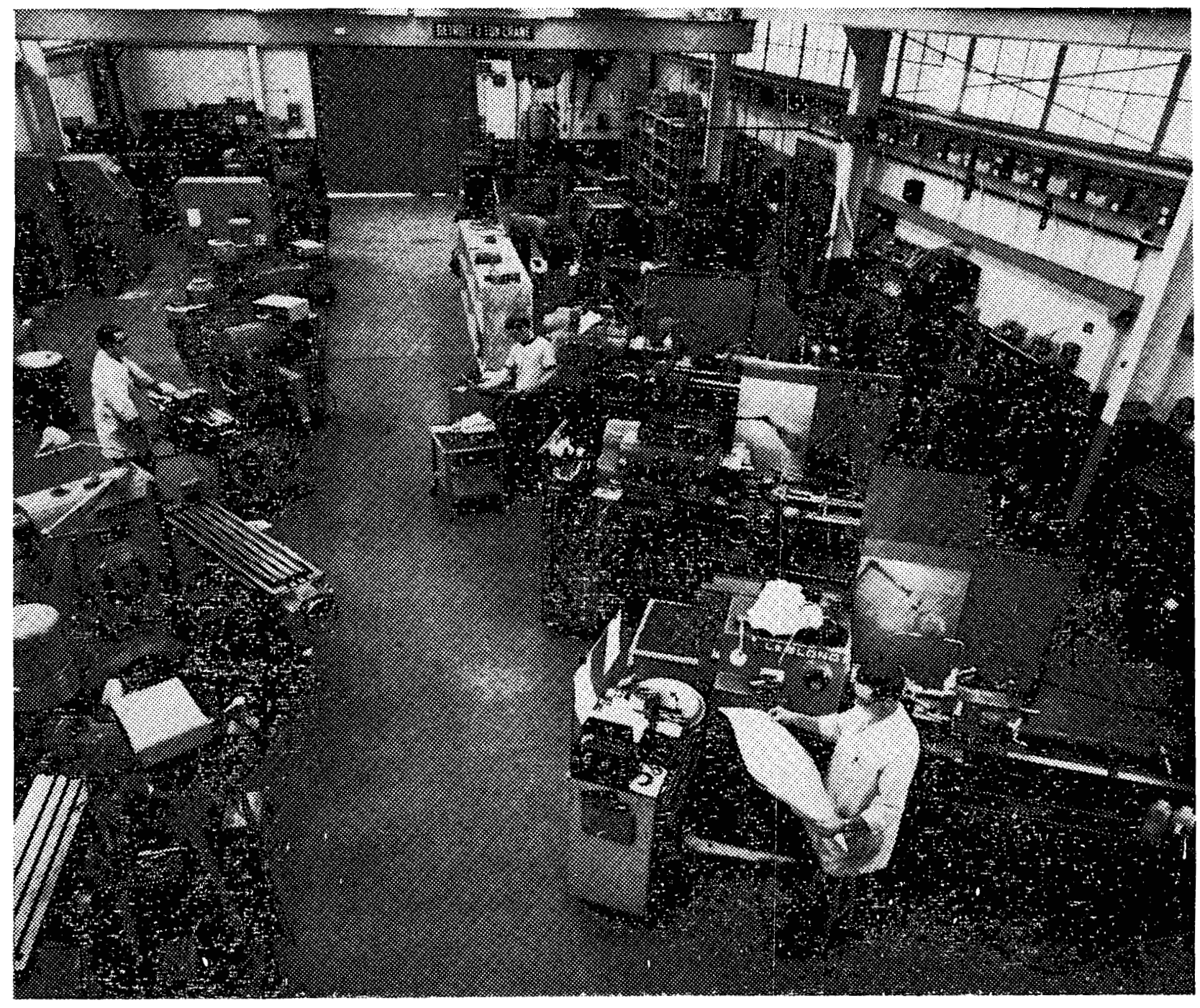

Fig, 6 .

TA-33 machine shop facil ity. 
C. Downhole Sonde Assembly and Test Laboratory

A large sonde assembly and test laboratory provides necessary tools and equipment to assemble and check out all downhole instrument systems before deployment in the field. All critical components and subassemblies are carefully inspected here to ensure integrity of the system before they are subjected to the severe geothermal environment. A helium leak detection test is performed on the final assembled iristrument. Motors, transducers, locking arms, caliper arms, and electronic systems are checked for calibration and proper operation (Fig. 7 ).

Following each borehole survey, the sondes are returned to the assembly and test laboratory where they are disassembled and again inspected for possible defects, wear, or malfunctions. Pressure seals are replaced. Records are kept of the tool's performance, and modifications are initiated to improve performance and facilitate easier handing in the field.

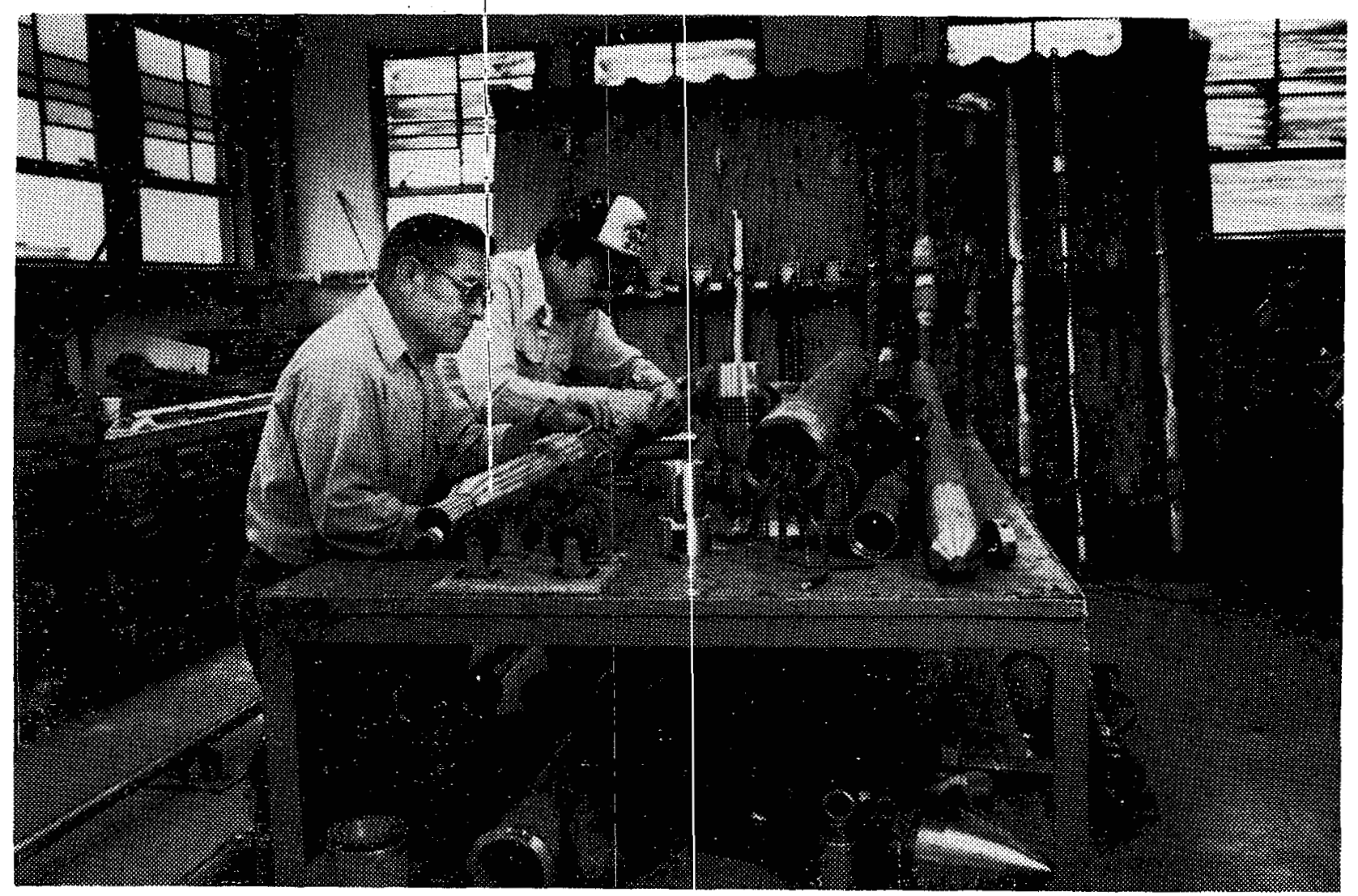

Fig. 7.

Downhole sonde assembiy and test laboratory. 


\section{Electronic Design and Computer Facil it ies}

The electronic signal-conditioning and line-driving circuitry for each downhole instrument system has its own unique characteristics. These special circuits are designed and fabricated in the Electronics Design Laboratory. Downhole electronic circuits are interfaced to surface data acquisition systems for storage and on-line displays.

The data acquisition systems presently in use are designed for low-level signal measurements from the remote downhole sensors where the data communication link (armored wireline logging cable) provides signal transmission. All signal conditioning, grounding, and shielding use guarded differential techniques to optimize maximum signal-to-noise and common-mode rejection. Data are digitized, normalized, and fitted to calibration information, then displayed and stored in engineering units.

The signal-conditioning and data acquisition system for acoustic detection is unique. Signals detected by triaxial geophones and accelerometers are transmitted to a Biomation storage scope with a circulating memory. This unit triggers on the present amplitude of the incoming microseismic signal and provides a delay sweep that allows display of several milliseconds of signal obtained prior to the trigger. An interface bus designed at the Laboratory allows the computer equipment to talk to the Biomation units, control the entire acoustic detection system, and store the desired signals on disk units for on-line processing to determine source orientation and distance from the detector. Now fracture growth can be observed on 1 ine in real time. The relative complexity of the software programs to make this system work requires programming in assembly language to obtain high-speed data transfer. The technology developed here to perform acoustic mapping in a geothermal environment is rapidly gaining interest in the industry.

A data acquisition and control system that duplicates the instrumentation hardware installed at Fenton $\mathrm{Hill}$ is located at TA-33. This system is used to check out downhole tool operations in the laboratory and to write the computer programs required for each tool. This equipment is used to design and develop special computer peripheral interfaces for such things as PCM, FM multiplex, and FFT analyzers. Programs are written and checked out here for all downhole logging and reservoir measurement systems (Fig. 8). 


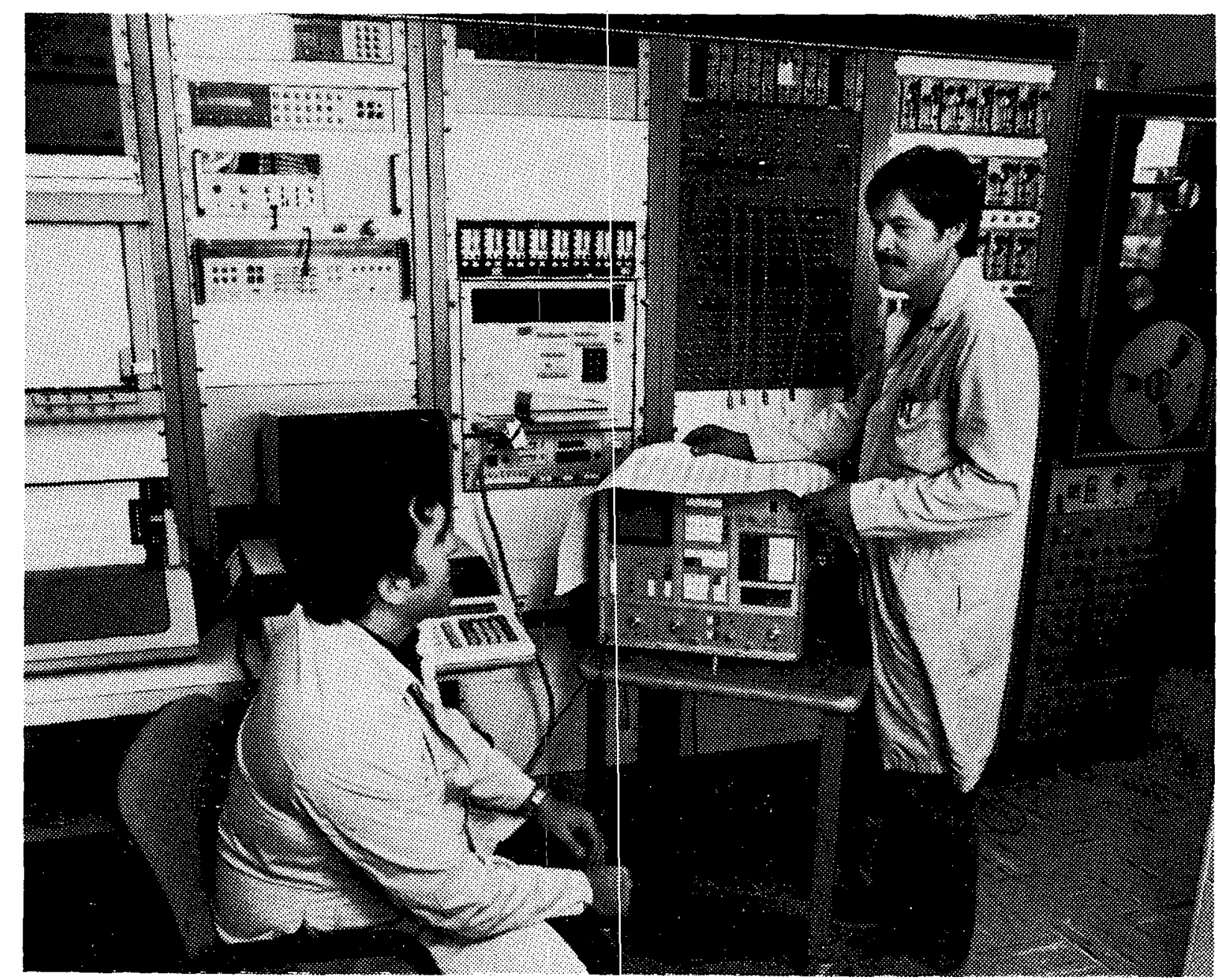

Fig. 8.

Electronic design and computer laboratory.

\section{E. Geothermal Well bore Logging Equipment}

To meet the ever-increasing demands for wellbore data in the HDR Project, instrumentation and data acquisition systems were designed to be compatible with the spectrum of high-temperature, downhole survey tools that were developed for the Project. The instrumentation systems have been installed in two diesel-driven logging trucks referred to as wellside service units. The trucks have an International Harvester chassis with a Cummings diesel engine and hydraulically controlled drawworks (Fig. 9). The trucks and associated drawworks were outfitted by Energy Products of Ft. Worth, Texas. Each truck is equipped with $6000 \mathrm{~m}(20,000 \mathrm{ft})$ of $11.1-\mathrm{mm}$-diam (7/16-in.), 7-conductor, TFE Teflon-insulated armored cable. The TFE Teflon is rated for continuous 


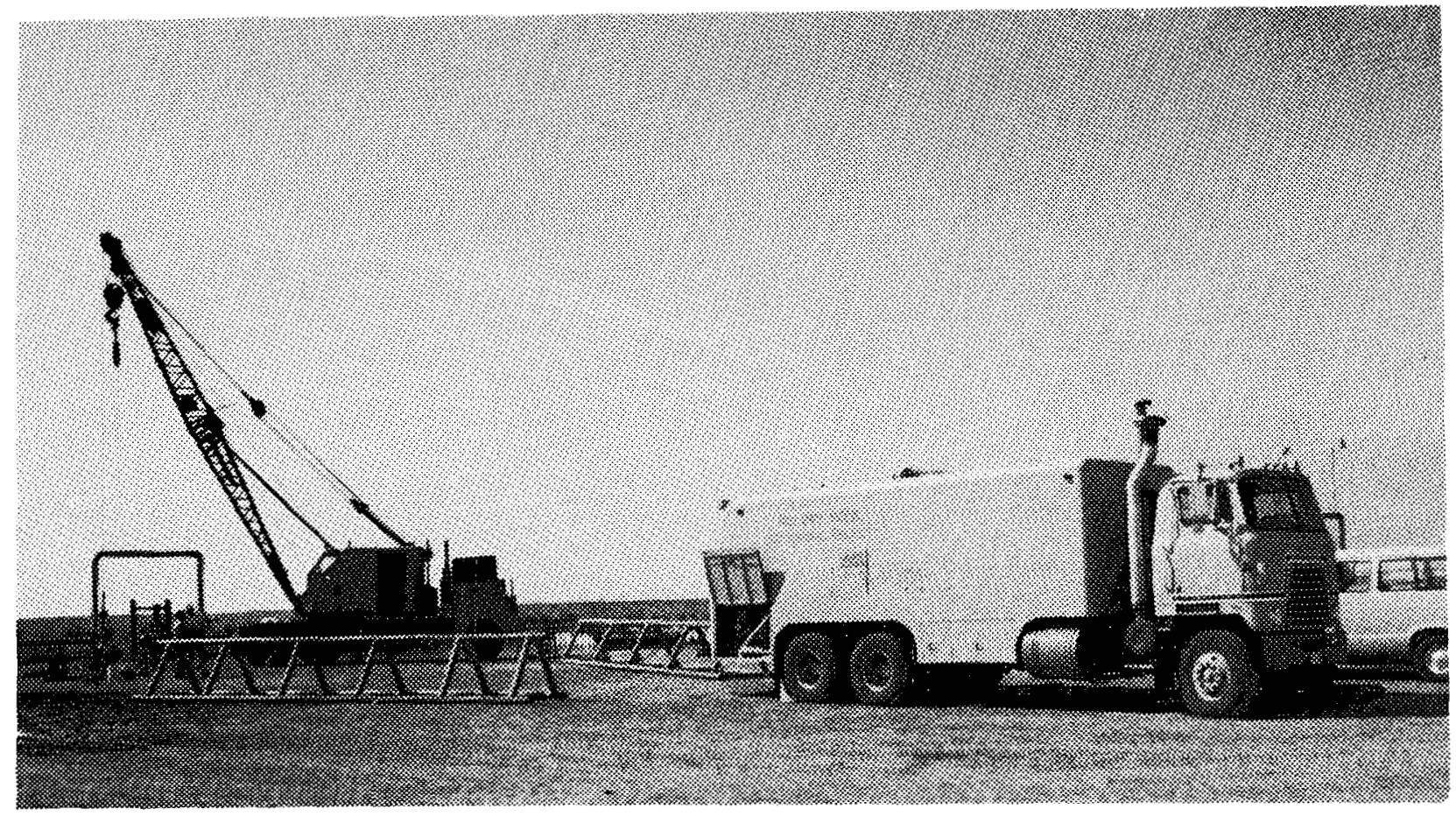

Fig. 9.

Wellside Service Unit No. 4.

service to $320^{\circ} \mathrm{C}\left(610^{\circ} \mathrm{F}\right)$ and has been tested in the cable test autoclave at $350^{\circ} \mathrm{C}\left(662^{\circ} \mathrm{F}\right)$. The armor package on the cable is improved galvanized plow steel and is well suited for work in the HDR boreholes.

The wellside service units carry two internal 6.5-kVA generators, self-contained air conditioner units, and complete measuring head systems.

The wellside service units have been used to deploy various borehole survey instruments at many locations where the DOE and industry have conducted well-stimulation and other experiments.

In addition to the two wellside service units, there are two trailer-mounted diesel-driven "offshore" logging rigs permanently stationed at the Fenton $\mathrm{Hill}$ site. One of these rigs is equipped with $6000 \mathrm{~m}(20,000 \mathrm{ft})$ of Tefzel Teflon-insulated, 7-conductor armored cable used primarily in the Phase I wellbores where downhole temperatures do not exceed $200^{\circ} \mathrm{C}\left(392^{\circ} \mathrm{F}\right)$. The second $\mathrm{rig}$ is equipped with $6000 \mathrm{~m}(20,000 \mathrm{ft})$ of the high-temperature TFE, 7-conductor cable. The data acquisition and recording equipment is shared by both offshore rigs and is housed in the central Data Acquisition Trailer. 


\section{F. High-Temperature Components}

Critical components exposed to the geothermal environment mandate the upper limitations of downhole instrument systems operations. The Los Alamos National Laboratory has pursued the development of such critical components including logging cable, 0-ring seals, transducers, motors, and connectors primarily through industrial contracts.

L'Garde, Inc., developed a high-temperature elastomer called EPDM-Y267 compound for 0-rings and other components used in the Laboratory's high-temperature downhole tools. The 0-rings were tested by temperature and pressure cycling to determine operating characteristics at $300^{\circ} \mathrm{C}\left(572^{\circ} \mathrm{F}\right)$ and $69 \mathrm{MPa}(10,000 \mathrm{psi})$. These 0 -rings are now commercially available from Parker Seal Company.

Smal1, high-temperature dc motors were designed by American Electronics, Inc. The motors are used in devices such as the fluid sampler, geophone tools, and tracer injector on an internittent basis. Motors have been tested for 8 hours of operation at $275^{\circ} \mathrm{C}\left(527^{\circ} \mathrm{F}\right)$.

An armored, 7-conductor cable with TFE Teflon used for the electrical insulating material was manufactured for the Laboratory by the Rochester Corporation. Extensive tests show TFE Teflon, although nonextrudable, to be the best wireline insulation material presently available for use above $320^{\circ} \mathrm{C}$ $\left(610^{\circ} \mathrm{F}\right)$.

Extensive frequency response tests were conducted on the new 7-conductor, TFE Teflon-insulated, armored cable. Tests conducted over $6000 \mathrm{~m}(20,000 \mathrm{ft})$ of the cable show a corner frequency response of greater than $10 \mathrm{kHz}$, which is a factor of 10 better than either the standard Tefzel or the PFA Tefloninsulated logging cables. The data also show that the response is down only $20 \mathrm{~dB}$ at $100 \mathrm{kHz}$. Frequency response enhancement may be achieved by careful selection of particular conductors for signal lines that are coupled with proper cable termination impedance.

One of the most critical components of the downhole instrument package is the cablehead, which provides the downhole termination of the armored, 7-conductor, logging cable and completes the transition to the instrument sonde. The cablehead ensures watertight integrity of the electrical wire terminations that is so important in the high-temperature environment. It al so allows a disconnect from the armored cable should the sonde become stuck 
in the borehole. The cablehead, designed by the Laboratory, has been subjected to numerous logging runs in geothermal environments in fluid temperatures exceeding $300^{\circ} \mathrm{C}\left(572^{\circ} \mathrm{F}\right)$, often for several hours of downhole operations.

A significant improvement in electrical connectors for downhole instrument packages was made by Reynolds Corporation under contract to the Laboratory. The new connectors are configured like the standard Amphenol but use a unique ceramic insert that is made from a mold and is machinable during the curing process. This insert accepts the crimped pins that are readily inserted and removed from the ceramic feedthrus. This feature allows the connector to be reused many times. The connectors have been tested to $350^{\circ} \mathrm{C}$ $\left(662^{\circ} \mathrm{F}\right)$ with no observable degradation.

Acoustic tools developed at Los Alamos were designed to "map" fractures and characterize geothermal reservoirs. The series of downhole instruments include geophone acoustic detectors, acoustic transceivers, accelerometers, and explosive detonators to simulate seismic sources for cal ibration purposes.

The high-temperature geophone technology developed at Los Alamos has been transferred to industry. High-temperature geophones may be purchased from Mark Products in Houston, Texas. Low-frequency geophones (corner frequency below $30 \mathrm{~Hz}$ ) are affected by tilting the axis more than $14^{\circ}$ from the vertical. However, high-frequency geophones may be used in inclined positions greater than $80^{\circ}$ from the vertical.

An accelerometer acoustic detector may be used to complement the triaxial geophone array. Results of extensive testing show that the high-temperature Endevco piezoelectric accelerometer is best suited for the tools developed at Los Alamos. This accelerometer has a greater frequency range, the required electrical isolation, and the proper size for mounting in the limited space provided in the downhole sonde.

The explosive detonator system provides acoustic signals from a known, fixed location in one of the wellbores. These signals are used to calibrate the high-temperature triaxial geophone array deployed in adjacent wells. The downhole sonde is modular in design and is used to fire up to 12 detonators in sequence. Each detonator contains pellets of hexanitrostilbene (HNS) explosive and is a modified version of the Reynolds Industries RP-84 slapper initiator, which is used in other high-temperature explosive devices. The 
detonator is initiated by a downhole capacitive discharge firing unit, which is controlled through the armored instrumentation cable from the surface control unit. The firing circuit and detonator have operated successfully in well ibores where temperatures exceed $300^{\circ} \mathrm{C}\left(572^{\circ} \mathrm{F}\right)$.

other explosive devices use a themally stable explosive-shaped charge to perform specific functions. One such tool leaves a bell-shaped cavity in hard rock for sidetracking the wellbore. A second tool uses a shaped charge to cut off drill pipe leaving a clean circumferential edge for overshot tools. A fracture initiation tool is used to detonate a small explosive charge in a preselected zone in the open-hole section of the wellbore to initiate the fracture system by reducing the wellbore impedance. The thermally stable explosive has been tested to temperatures exceeding $340^{\circ} \mathrm{C}\left(644^{\circ} \mathrm{F}\right)$.

A summary of high-temperature components is given in Table I.

\section{LOOKING AHEAD}

The Laboratory's expertise in high-temperature borehole instrumentation has grown along with national and international interest in naturally heated rock as an attainable energy resource. The worldwide abundance of hot dry rock puts it within reach of many parts of the world when the technology and tools to use it are available. Los Alamos does, in fact, send members of its geothermal staff outside the US to help other governments assess their countries' geothermal potential and select sites for possible exploration. Many governments send representatives to Los Alamos for an on-site tour of Fenton $\mathrm{Hill}$ and briefings on the tool's and techniques used at the test facil ities.

West Germany and Japan are active participants in the project at Fenton Hill. Both countries contribute financial support and technical staff assistance under terms of an Internaticnal Energy Agreement signed by West Germany's Kernforschungsanlage Jülich Gmbh, Japan's New Energy Development Organization (NEDO), and the US DOE.

Technology exchange is one of the Laboratory's goals. The Earth Science Instrumentation Group is entering into more cooperative ventures and participating in an increasing number of geothermal tests and experiments with 


\section{Descript ion}

Acoust ic Window
Ampl ifier Operat ional
Ampl ifier Operat ional
Cable Armored Wirel ine
Cable Armored Wirel ine
Cablehead
Cablehead Boot
Connector
Connector--Microm iniature
Connector--Cablehead
Capacitor
Capacitor
Dewar
Detonator
Firing Module
High-Temperature Grease
Geiger-Müller Tube
Heat Pipe
Heat Sink
Motor--dc
Motor--ac
Oil
Oil
O-Ring
0-Ring
Printed Circuit Board
Printed Circuit Connector
Relay DPDT
Rel ief Valve
Resistor
Rotary Transformer
Slip Ring
Sl ip Ring Assembly
High-Temperature Solder
High-Temperature Tape
Transducers
Accelerometer
Accelerometer
Accelerometer Cable
Acoust ic Crystal
Acoust ic Crystal
Acoust ic Crystal
Collar Locator
Geophone
Magnetometer
Potent iometer
Pressure Transducer
Reed Relay
Thermistor
Voltage Regulator
Wire Hookup
Hito

Manu facturer

Los Al amos

Harris Electronics

Burr-Brown

Rochester Corporation

Vector Corporation

Los Al amos

Kemlon Products

Guiton Industries

ITT Cannon

Reynolds Industries

American Technical Ceramics

Corning Glass Works

Vacuum Barrier

Reynolds Industries

Reynolds Industries

E.I. DuPont Company, Inc.

Harshaw/F iltrol

Los Alamos

Los Alamos

American Electronics, Inc.

American Electronics, Inc.

Dow Corning

E.I. DuPont Company, Inc.

Parker Seal

Bal Seal

Circuit Shop

AMP

Teledyne

Lee Company

Allen Bradley

Ceramic Magnetics

Corning Glass Works

Los Alamos

Mult icore Solder

Boyd Industrial Rubber

BBN Instruments

Endevco

BBN Instruments

Channel Industries

Spec ialties Eng ineering

Keramos, Inc.

Gearhart

Mark Products

Humphrey

Litton Potent iometer

Bell \& Howell/CEC Division

Haml in

Conax Corporation

White Technology

Standard Wire and Cable

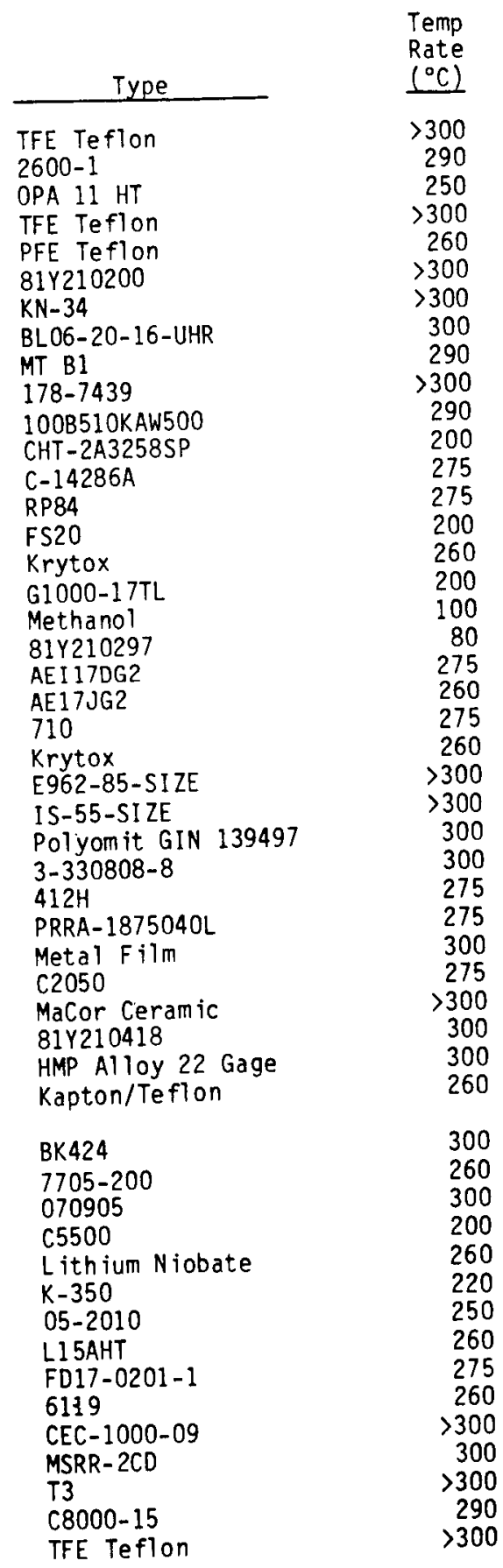


industry. As a result, new places and new ways are emerging to use the high-temperature equipment developed at Los Alamos (Fig. 10).

The Los Alamos tool developed to take fluid samples at discrete locations in geothermal wells at temperatures above $300^{\circ} \mathrm{C}\left(572^{\circ} \mathrm{F}\right)$ was used to sample the superheated $228^{\circ} \mathrm{C}\left(550^{\circ} \mathrm{F}\right)$ fluids issuing from the sea-floor vents under the Pacific Ocean off the west coast of Mexico. This work was done as part of a program sponsored by the National Science Foundation and University Consortium.

Laboratory acoustic tools were used successfully to map fractures in wel1-stimulation experiments at the Union Geothermal Development at the Baca Location in New Mexico.

An exploratory geothermal borehole was drilled to a total depth of $3064 \mathrm{~m}$ $(10,054 \mathrm{ft})$ for ORE-IDA Foods, Inc., into the hot basalt underlying the plant's facility in Oregon. The Laboratory ran a series of temperature and fluid velocity logs in this well to evaluate the reservoir for hot water production to be used for food processing and heat at the processing plant.

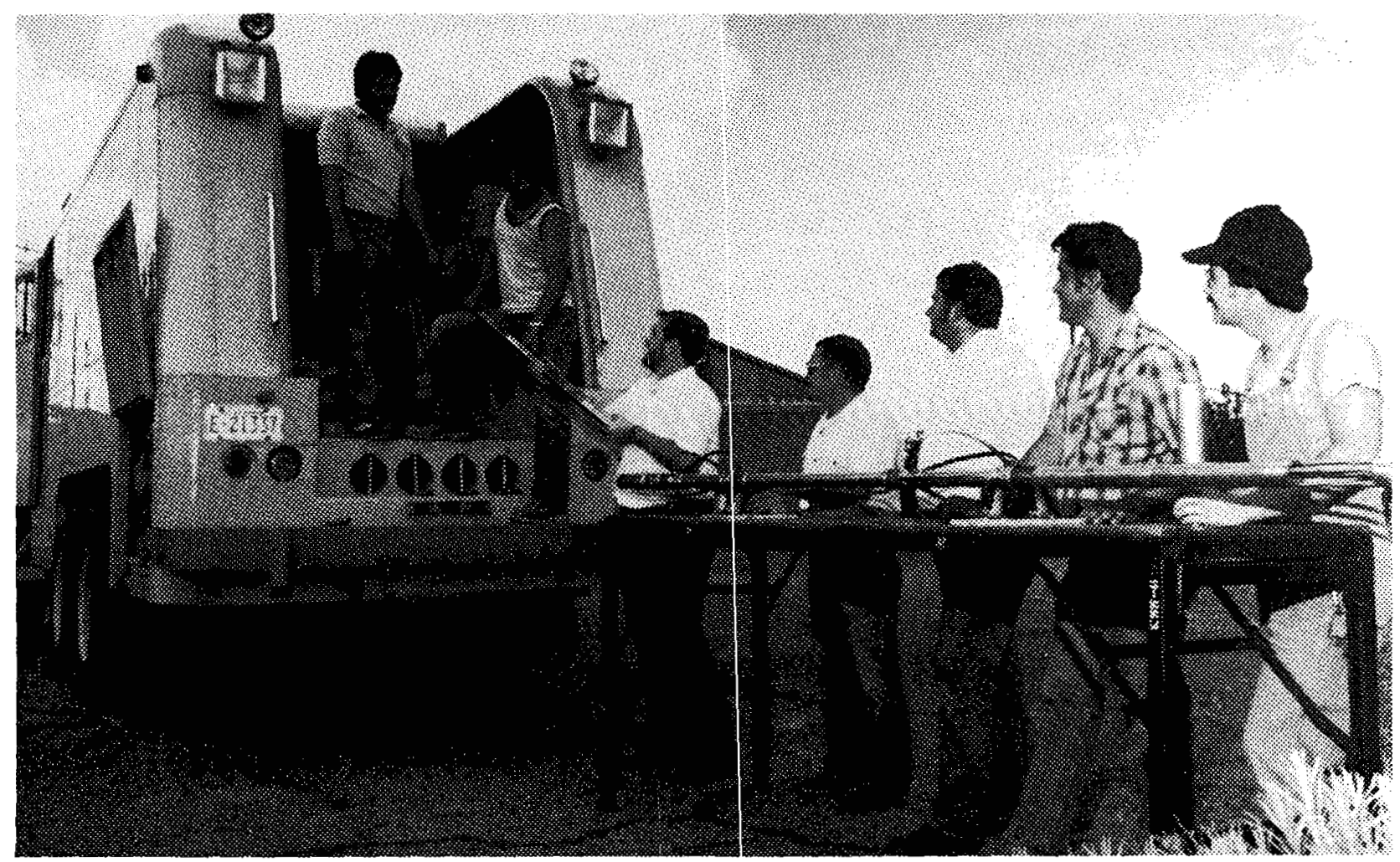

Fig. 10 .

Field crew checks downhole logging system. 
The DOE, Republic Geothermal, and Chevron Geothermal conducted a wellst imulation experiment in Beowawe, Nevada. The Laboratory participated in the experiment by deploying the geophone packages in a nearby well to record microseismic signatures during the borehole pressurization. Temperature logs were run in the pressurized well following the injection tests.

Recently, field personnel from the Earth Science Instrumentation Group participated in a unique geothermal borehole experiment with Phillips Petroleum Geothermal Division at a site near El Centro, California. Field operations consisted of two separate tests. The first test concerned the effects of the borehole fluids encountered in the sour wells drilled in the Imperial Valley on various armor materials used to manufacture well-logging cables. The second test involved extensive vertical seismic profile work, which was conducted in two wells using the Laboratory's high-temperature geophone package positioned at numerous locations in the borehole. Analys is of the recordings provided valuable information about the formation and potential reservoir.

The acoustic transceiver system was used to investigate formation structure between wellbores in the Tight Gas Sands Project at Rifle, Colorado. The magnetostrictive acoustic source was used to scan $100-\mathrm{ft}$ sections in one wellbore while the receiver was stationed in an adjacent wellbore. This technique was repeated to cross-scan three separate boreholes.

The acoustic systems and associated technology have been used in studies of devonian shales, oil shales, underground storage chambers, and telecommunications. Now there is interest expressed in using many of the high-temperature instruments in wells that are drilled in conjunction with the Deep Sea Drilling Program and the Continental Scientific Drilling Program.

\section{FUTURE DEVELOPMENTS}

The research and development work at Los Alamos will continue in a number of areas. The investigation of more efficient thermal protection devices has been intensified to provide both higher temperature working environments and longer term residence time in the wellbores. 
Research is progressing on a high-temperature bridgewire detonator that will el iminate need for a downhole firing circuit and will improve reliability. The new detonator will al so improve temperature capabil ities.

Investigation of improved armored cable has also intensified. Presently the logging cable accounts for many of the limitations to work in geothermal boreholes. Tests are in progress to determine effects of brines where sulfides and chlorides are present. Tests are also planned to determine work hardening of tubular cores used in available magnesium oxide-insulated cables. More studies are needed to determine cooling methods when retrieving cables from very hot wellbores.

Development of high-temperature electronics using special devices such as integrated thermionic circuits could extend reliable operation of logging tools up to temperatures exceeding $500^{\circ} \mathrm{C}\left(932^{\circ} \mathrm{F}\right)$.

other developments are continuing in a number of high-temperature components and transducers including pressure transducers, accelerometers, and acoustic crystals. The overall clevelopment of the high-temperature instruments and associated equipment resulting in many successful field operations in geothermal environments must be attributed to the personnel in the Earth Science Instrumentation Group and Branch Shop (Fig. 11). The staff of engineers and technicians are responsible for the research, design, fabrication, and testing of all the instrumentation systems and are directly involved in the field operations as well. Operating the equipment in the field provides a great advantage: an appreciation of the many problems associated with assembly, check-out, and maintenance of these systems under field conditions. Many significant improvements in instrument design, especially in areas of ruggedness, reliability, and field assembly, have come from inspirations during actual field deployment.

\section{ACKNOWLEDGMENTS}

We thank the many industrial companies that supported our research and contributed to the component and equipment development that has made our high-temperature capabilities possible. We also acknowledge the contributions of other intradivisional personnel at Los Alamos whose expertise in all areas of this development work was necessary and much appreciated. 


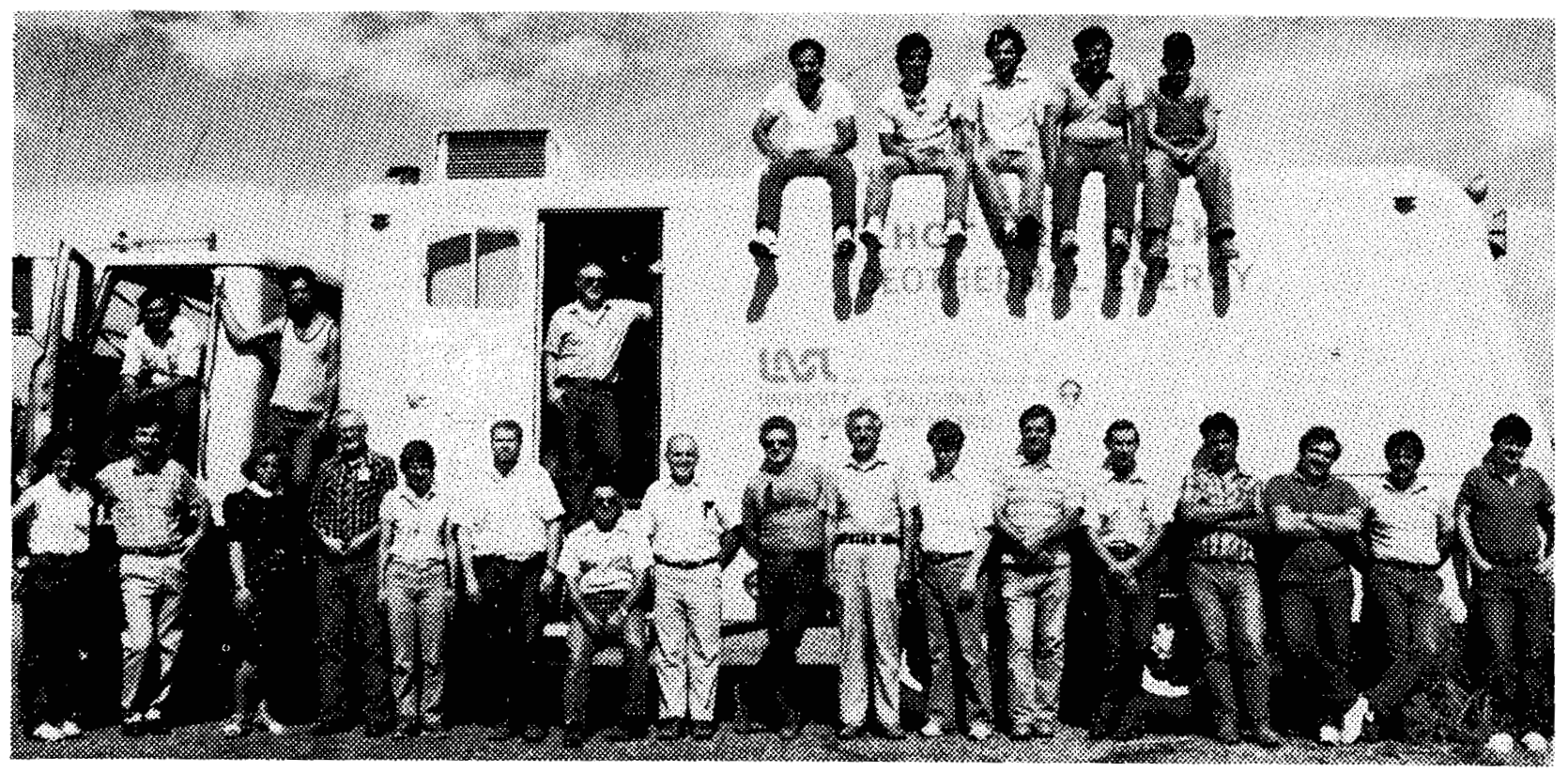

Fig. 11 .

It's a tough job but somebodies have to do it!

\section{BIBLIOGRAPHY}

1. R. A. Pettitt, "Planning, Drilling, and Logging of Geothermal Test Hole GT-2, Phase I," Los Alamos Scientific Laboratory report LA-5819-PR (January 1975).

2. R. A. Pettitt, "Testing, Drilling, and Logging of Geothermal Test Hole GT-2, Phase II," LoS Alamos Scient ific Laboratory report LA-5897-PR (March 1975).

3. R. A. Pettitt, "Testing, Drilling, and Logging of Geothermal Test Hole GT-2, Phase III," Los Alamos Scientific Laboratory report LA-5965-PR (June 1975).

4. J. N. Albright, "Temperature Measurements in the Precambrian Section of Geothermal Test Hole No. 2," Los Alamos Scientific Laboratory report LA-6022-MS (July 1975).

5. F. G. West, P. R. Kintzinger, and A. W. Laughl in, "Geophysical Logging in Los Alamos Scientific Laboratory Geothermal Test Hole No. 2," Los Alamos Scient if ic Laboratory report LA-6112-MS (November 1975).

6. W. L. Sibbitt, "Preliminary Measurements of the Thermal Conductivity of Rocks from LASL Geothermal Test Holes GT-1 and GT-2," Los Alamos Scient ific Laboratory report LA-6199-MS (January 1976). 
7. R. A. Pettitt, "Planning, Drilling, Logging, and Testing of Energy Extraction Hole EE-1, Phases I and II," LoS Alamos Scient ific Laboratory report LA-6906-MS (August 1977).

8. HDR Project Staff, "Hot Dry Rock Geothermal Energy Development Project, Annual Report, Fiscal Year 1977," Los Alamos Scientific Laboratory report LA-7109-PR (February 1978).

9. J. R. Archuleta, C. F. Fink, and J. Kurtenbach, "Equipment Development Report, Downhole Fluid Injector," Los Alamos Scientific Laboratory report LA-7151-MS (February 1978).

10. J. R. Archuleta, C. F. Fink, and J. Kurtenbach, "Equipment Development Report, Borehole-Fluid Sampling Tool," Los Alamos Scientific Laboratory report LA-7152-MS (February 1978).

11. J. B. McCormick, "Progress in the Development of Microelectronics for the $500^{\circ} \mathrm{C}$ Environment," High-Temperature Electronics Workshop, Los Alamos, NM, January 4-6, 1978, Los ATamos Scient ific Laboratory report LA-7409-C (July 1978).

12. J. R. Archuleta and B. E. Todd, "Hot Dry Rock Geothermal Energy Development Project Cablehead Assembly, Equipment Development Report," Los Alamos Scient ific Laboratory report LA-7325-MS (August 1978).

13. J. W. Tester and J. N. Albright, "Hot Dry Rock Energy Extraction Field Test: 75 Days of Operation of a Prototype Reservoir at Fenton Hill, Segment 2 of Phase I," Los Alamos Sc ient ific Laboratory report LA-7771-MS (April 1979).

14. HDR Program Staff, "Hot Dry Rock Geothermal Energy Development Program, Annual Report, Fiscal Year 1978," Los Alamos Scientific Laboratory report LA-7807-HDR (April 1979).

15. W. W. Patterson, D. R. Deam, H. J. MacDonald, and R. H. Rochester, "Capacitive Discharge Firing System for Providing Acoustic Sources in the Hot Dry Rock Geothermal Energy Development Project," Los Alamos Scient ific Laboratory report LA-7761-MS (July 1979).

16. S. K. Sanyal, L. E. Wells, and R. E. Bickham, "Geothermal Well Log Interpretation--State of the Art, Final Report," LOS ATamos Scientific Laboratory report LA-8211-MS (January 1980).

17. H. D. Murphy, R. L Aamodt, J. N. Albright et al., "Prel iminary Evaluation of the Second Hot Dry Rock Geothermal Energy Reservoir: Results of Phase I, Run Segment 4," Los Al-amos Scientific Laboratory report LA-8354-MS (May 1980).

18. G. M. Cremer, R. B. Duffield, M. C. Smith, and M. G. Wilson, "Hot Dry Rock Geothermal Energy Development Frogram, Annual Report, Fiscal Year 1979, "Los Alamos Scientific Laboratory report LA-8280-HDR (August 1980). 
19. G. M. Cremer, R. B. Duffield, G. J. Nunz et al., "Hot Dry Rock Geothermal Energy Development Program Annual Report, Fiscal Year 1980," Los Alamos National Laboratory report LA-8855-HDR (JuTy 1981).

20. M. C. Smith and G. M. Ponder, "Hot Dry Rock Geothermal Energy Development Program, Annual Report, Fiscal Year 1981," Los Alamos National Laboratory report LA-9287-HDR (April 1982).

21. C. Helmick, S. Koczan, and R. A. Pettitt, "Planning and Drilling Geothermal Energy Extraction Hole EE-2, A Precisely Oriented and Deviated Hole in Hot Granitic Rock," Los Alamos National Laboratory report LA-9302-HDR (April 1982).

22. S. P. Koczan, W. W. Patterson, and R. H. Rochester, "Drill-Pipe Severing Tool with High-Temperature Explosive," Los Alamos Scientific Laboratory report LA-9483-MS (August 1982).

23. G. A. Bennett and G. R. Sherman, "Analysis and Thermal Design Improvements of Downhole Tools for Use in Hot Dry Wells," Los Alamos National Laboratory report LA-9671-HDR (February 1983).

24. M. C. Smith, G. J. Nunz, and G. M. Ponder, "Hot Dry Rock Geothermal Energy Development Program, Annual Report, Fiscal Year 1982," Los A1amos National Laboratory report LA-9780-HDR (September 1983).

25. M. C. Smith, G. J. Nunz, and M. G. Wilson, "Hot Dry Rock Geothermal Energy Development Program Annual Report Fiscal Year 1983," Los Alamos Nationa1 Laboratory report LA-10347-HDR (February 1985).

26. R. Lawton, J. Kolar, and B. Todd, "Fluid Velocity Sensor-Development Report, Hot Dry Rock Geothermal Energy Development Project," Los Alamos National Laboratory publication LALP-82-16.

27. M. C. Smith, "Major Accomplishments of the Hot Dry Rock Program, 1970-1982," Los Alamos National Laboratory publ ication LALP-82-37.

28. B. R. Dennis and B. E. Todd, "Transducer Technology for Deep Borehole Geothermal Environments," Los Alamos Scientific Laboratory document LA-UR $-75-723$.

29. J. N. Albright, "A New and More Accurate Method for the Direct Measurement of Earth Temperature Gradients in Deep Boreholes," Los Alamos Scient ific Laboratory document LA-UR-75-952.

30. F. G. West, P. R. Kintzinger, and A. W. Laughl in, "Geophys ical Logging in Los Alamos Scient ific Laboratory Geothermal Test Hole No. 2," LoS Alamos Scient ific Laboratory document LA-UR-75-1518.

31. B. R. Dennis, J. H. Hil1, E. L. Stephani, and B. E. Todd, "Development of High-Temperature Acoustic Instrumentation for Characterization of Hydraul ic Fractures in Dry Hot Rock," 2nd Int. Instrumentation Symp., San Diego, CA, May 25-27, 1976, Los Alamos Scientific Laboratory document LA-UR $-76-493$. 
32. J. N. Albright and R. J. Hanold, "Seismic Mapping of Hydraulic Fractures Made in Basement Rock," 2nd Annual ERDA Symp. on Enhanced $0 i 1$ and Gas Recovery, Tulsa, OK, September 9.-10, 1976, Los Alamos Scientific Laboratory document LA-UR-76-1865.

33. H. D. Murphy and R. G. Lawton, "Downhole Measurements of Thermal Conductivity in Geothermal Reservoirs," Los Alamos Scient ific Laboratory document LA-UR-77-624.

34. J. R. Archuleta, "Downhole Geothermal Sondes," Los Alamos Scientific Laboratory document LA-UR-77-749.

35. B. R. Dennis and E. H. Horton, "Hot Dry Rock, An Alternate Geothermal Energy Resource--A Challenge for Instrumentation," Los Alamos Scient ific Laboratory document LA-UR-78-707.

36. B. R. Dennis and H. D. Murphy, "Borehole Temperature Survey Analys is Hot Dry Rock Geothermal Reservoir," Los Alamos Scientific Laboratory document LA-UR -78-905.

37. B. R. Dennis, "Materials for High-Temperature Geothermal Borehole Instrumentation Cable," Los Alamos Scientific Laboratory document LA-UR-78-1517.

38. J. N. Albright, R. L. Aamodt, R. M. Potter, and R. W. Spence, "Acoust ic Methods for Detecting Water-Filled Fractures Using Commercial Logging Tools," Los Alamos Scient ific Laboratory document LA-UR-78-1826.

39. J. B. McCormick and D. K. Wilde, "Development of Integrated Thermionic Circuits for Geothermal High-Temperature Applications," Los Alamos Scient ific Laboratory document LA-UR-79-723.

40. R. G. Lawton and E. H. Horton, "Data Acquisition for the Hot Dry Rock Geothermal Energy Project," Los Alamos Scientific Laboratory document LA-UR-79-812.

41. B. R. Dennis, "Borehole Survey Instrumentation Development for Geothermal Applications," Los Alamos Scient ific Laboratory document LA-UR-80-670.

42. J. N. Albright, C. F. Pearson, and M. C. Fehler, "Transmission of Acoustic Signals through Hydraulic Fractures," Los Alamos Scientific Laboratory document LA-UR-80-772.

43. B. R. Dennis and R. G. Lawton, "High-Temperature Cable Test Program for Geothermal Well Logging," Los Alamos Scientific Laboratory document LA-UR-80-1692.

44. M. C. Smith, "A History of Hot Dry Rock Geothermal Systems," Los Alamos National Laboratory document LA-UR-81-1037.

45. B. R. Dennis, R. M. Potter, and J. D. Kolar, "Radioactive Tracers Used to Characterize Geothermal Reservoirs," Los Alamos National Laboratory document LA-UR-81-1769. 
46. M. G. Fehler and C. F. Pearson, "Cross-Hole Seismic Surveys: Applications for Studying Subsurface Fracture Systems at Hot Dry Rock Geothermal Site," Los Alamos National Laboratory document LA-UR-82-122.

47. 0. Nishizawa, C. Pearson, and J. Albright, "Properties of Seismic Wave Scattering Around Water Injection Well at Fenton Hill Hot Dry Rock Geothermal S ite," Los Alamos National Laboratory document LA-UR-82-2015.

48. B. R. Dennis, "High-Temperature Borehole Instrumentation," Conf. on Borehole Measurements and Interpretation in Scientific Drilling, Albuquerque, NM, November 15-17, 1983, Los Alamos National Laboratory document LA-UR-83-3176.

49. B. A. Robinson, "Fractured Geothermal Reservoir Analys is Using Radioactive Tracers," Conf. on Borehole Measurements and Interpretation in Scientific Drilling, Albuquerque, NM, November 15-17, 1983, Los Alamos National Laboratory document LA-UR-83-3178.

50. J. N. Albright and D. A. Terry, "Seismic Measurements in Deep Boreholes," Int. Symp. on Obs. of Cont. Crust Through Drilling, Tarrytown, NY, May 20-25, 1984, Los Alamos National Laboratory document LA-UR-83-3493.

51. R. Batra, J. N. Albright, and C. Bradley, "Downhole Seismic Monitoring of an Acid Treatment in the Beowawe Geothermal Field," GRC Annual Meeting, Reno, NV, August 1984, Los Alamos National Laboratory document LA-UR-84-1106.

52. B. R. Dennis, "Logging Technology for High-Temperature Geothermal Boreholes," Int. Symp. on Obs. of Cont. Crust Through Drilling, Tarrytown, NY, May 20-25, 1984, Los Alamos National Laboratory document LA-UR-84-1639.

53. H. D. Murphy and M. C. Fehler, "Seismic Observations of Hydraulic Fracturing of Granite Rock in a Hot-Dry Rock Geothermal Reservoir," AGU Fall Meeting, San Francisco, CA, December 3-7, 1984, Los Alamos National Laboratory document LA-UR-84-2793.

54. H. Keppler, "Hypocenters of Hydraulically Induced Microearthquakes Obtained by a Double Sonde Hodograph Method," AGU Fall Meet ing, San Francisco, December 3-7, 1984, Los Alamos National Laboratory document LA-UR-84-2795.

55. T. K. Moore, K. Hinz, and J. Archuleta, "Development of a New Borehole Acoustic Televiewer for Geothermal Applications," GRC Annual Meeting, Kona, HI, August 26-30, 1985, Los Alamos National Laboratory document LA-UR-85-925.

56. T. Grant, "Examination of Insulation Wear Modes in Geothermal Logging Cable," GRC Annual Meeting, Kona, HI, August 26-30, 1985, Los Alamos National Laboratory document LA-UR-85-926. 
57. G. A. Bennett, "Upgrades in Thermal Protection for Downhole Instruments," GRC Annual Meeting, Kona, HI, August 26-30, 1985, Los Alamos National Laboratory document LA-UR-85-927.

58. J. D. Kolar, B. R. Dennis, E. L. Stephani, and P. Gutierrez, "Space-Age Telemetry for Geothermal Well Logging--The Wirel ine Transmission Link," GRC Annual Meeting, Kona, HI, August 26-30, 1985, Los Alamos National Laboratory document LA-UR-85-928.

59. L. House, H. Keppler, and H. Kaieda, "Seismic Studies of a Massive Hydraulic Fracturing Experiment," GRC Annual Meeting, Kona, HI, August 26-30, 1985, Los Alamos National Laboratory document LA-UR-85-933.

60. J. T. Rutledge, J. N. Albright, and R. Batra, "Downhole Seismic Noise Measurements in the Beowawe Geothermal Field, Nevada," GRC Annual Meeting, Kona, HI, August 26-30, 1985, Los Alamos National Laboratory document LA-UR-85-1006. 


\section{APPENDIX}

\section{HIGH-TEMPERATURE BOREHOLE INSTRUMENTS}

A variety of high-temperature borehole instruments have been developed for use in the HDR Fenton $\mathrm{Hill}$ boreholes. The downhole systems have been designed to operate at temperatures between $275^{\circ} \mathrm{C}\left(527^{\circ} \mathrm{F}\right)$ and $320^{\circ} \mathrm{C}\left(610^{\circ} \mathrm{F}\right)$ and at pressures up to $103.4 \mathrm{MPa}(15,000 \mathrm{psi})$. The downhole instruments that have been used for numerous wellbore surveys are 1 isted and described in this append $i x$.

Note that the technical staff responsible for the design and testing of these high-temperature tool components, subassemblies, and instrument packages in the shop is also responsible for their deployment and operation in the field. Significant improvements in the instrument sonde design have resulted from the extensive exposure to field conditions. A high degree of reliability and efficiency in field assembly and operational techniques has been achieved. It should also be emphasized that many of the tools described must operate continuously for downhole residence times ranging from 4 hours to 30 hours.

\section{ACOUSTIC MEASUREMENTS}

A passive method by which acoustic signals are detected and used to "map" fractures has been under intense development for the HDR Program. This method uses downhole triaxial geophone instruments to detect acoustic signals generated during pressurization or inflation of the hydraulic fracture systems.

The acoustic events detected by the downhole geophone array contain the compressional or $\mathrm{P}$-wave followed by a second prominent arrival, the shear or S-wave. Independent knowledge of the propagation velocity in the reservoir rock enables the distance to the origin of the acoustic signal to be directly calculated. The particle motion at the detector on arrival of the $P$-wave is polarized in the direction of propagation. The determination of signal polarization can then be used to evaluate the direction to the acoustical event. The locus of the signal's origins defines the fracture location. Typicaliy, three acoustic detectors (geophone sondes) are deployed in three 
separate boreholes during hydraulic-fracture or pressurization experiments at the Fenton $\mathrm{Hill}$ site.

The active interrogation method uses an acoustic source transmitter that "scans" a section of one wellbore, while a receiver is stationed in the adjacent wellbore. The transmitter houses a 3-J magnetostrictive source that operates at a frequency of $8.5 \mathrm{kHz}$. The transmitter can be triggered at rates of up to 5 pps. A shot break crystal mounted coaxially with the transducer scroll provides a zero time for each pulse. The receiver consists of a piezoelectric transducer that has an equivalent response at the transmission frequency. The receiver gain can be controlled automatically downhole or manually from the surface control unit. The characteristics of the medium through which the acoustic vibrations pass are deduced from the character of the received signals and from their arrival times at the detector. The distance between two boreholes can be measured with considerable accuracy, and the presence of fluid-filled fractures in the formation can be determined.

A third acoustic system is the borehole acoustic televiewer. The Los Alamos version of the acoustic televiewer was developed jointly with Westfal ische Berggewerkschaftskasse (WBK) of West Germany. It has been designed for optimum operations in high-temperature wellbores, is of modular construction to facilitate field assembly and maintenance, and uses a microprocessor in the downhole electronics subsystem to control data collection and transmission. As the tool moves along the borehole, ultrasonic pulses are fired from the rotating head. The amplitude and travel time of the reflected pulses are measured by the dowrihole electronics, then conditioned and transmitted to the surface through the logging cable. The processed data provide a plain view of the wellbore wall. The instrument may also be used for casing inspection.

\section{I1. DOWNHOLE EXPLOSIVE DEVICES}

Explosive systems have many important applications in geothermal boreholes. Remedial operations during drilling and well completion work often require downhole explosives for casing and drillpipe cutting tools, drill pipe backoff shots, and explosive casing perforations. Explosive devices that were developed for the HDR Project were used for microseismic 
source simulation for emplaced geophone calibrations, wellbore fracture initiation, and sidetracking in hard rock formations.

Primarily, efforts to design downhole explosive devices have been concentrated on developing reliable high-temperature detonators and associated firing systems. There are stable high-temperature explosives commercially available, but some attention must be paid to contaminates in the explosive mixture. The LoS Alamos detonators, presently used in the Laboratory's downhole tools, are slapper-type bridgewire with an HNS explosive initiator and a PBX secondary. These detonators require a downhole firing unit. However, research is continuing to develop a high-temperature bridgewire detonator that does not require a downhole firing unit. The major accomplishment of explosive tool development at Los Alamos has been the safe use of thermally stable explosives with proven reliability. 


\section{Cablehead Assembly}

The cablehead assembly provides a cable-to-sonde electromechanical coupling device, which protects the electrical conditions from the highpressure/high-temperature environment. It establishes a transition area from the downhole-fluid, high-pressure environment to a dry, low-pressure instrument chamber. The cablehead assembly is a protected area for splicing the cable conductor ends to the high-temperature bulkhead.

Should the instrument sonde become lodged in the wellbore, the cablehead is designed to allow separation of the sonde and cable. The fishing bell housing then provides a positive gripping area for overshot fishing tools for retrieval from the borehole (Fig. A-I).

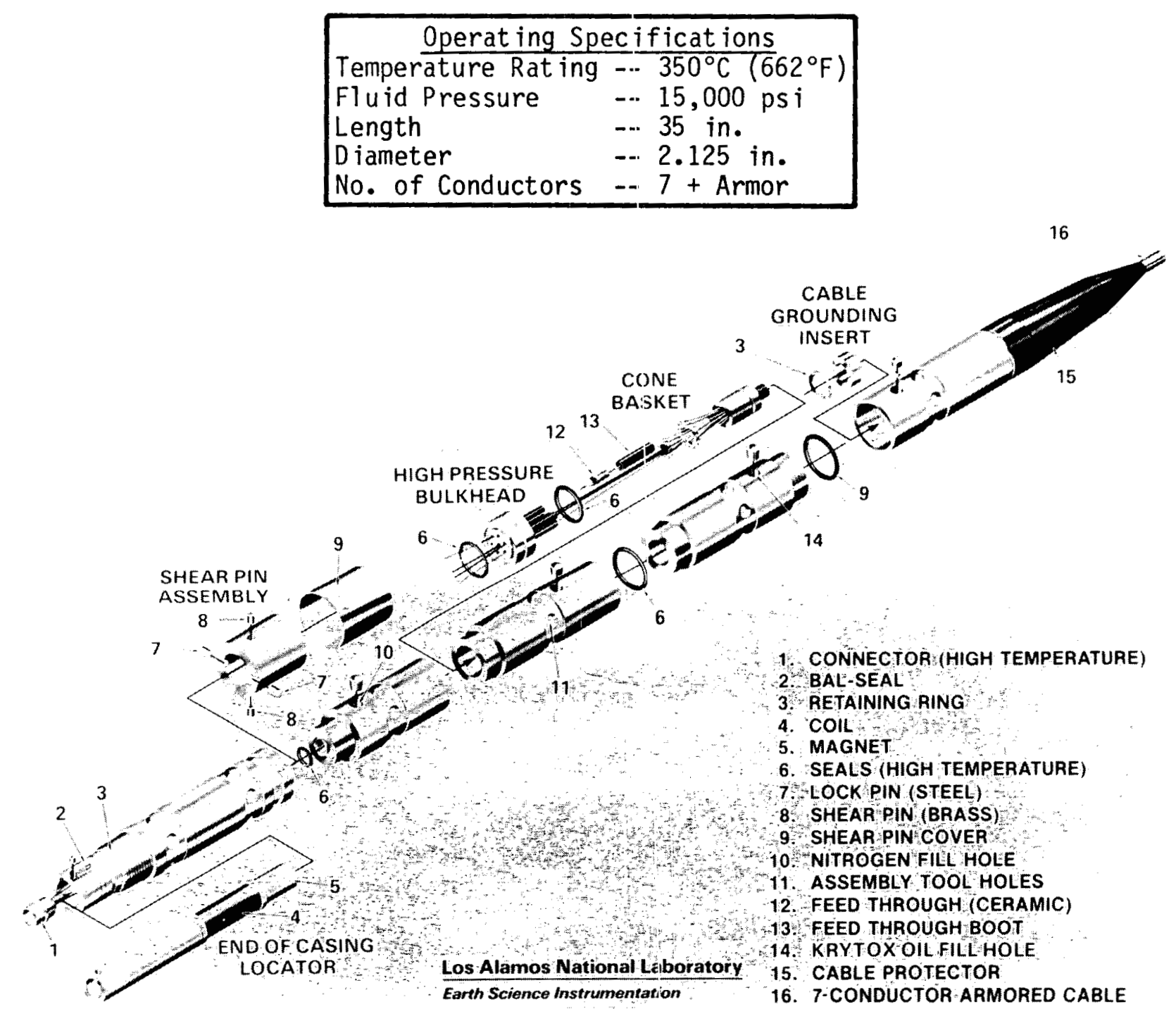

Fig. A-1.

Cablehead assenbly. 


\section{Borehole Fluid Sampler}

The borehole fluid sampler uses three conductors of the high-temperature armored instrument logging cable. The tool takes two separate samples of 270 $\mathrm{cm}^{3}$ or one large sample of $780 \mathrm{~cm}^{3}$. Chemical analyses of the fluid samples, which are taken at various depths in a borehole, show geothermal reservoir properties. The sample size is easily changed to accommodate quite large samples.

The dc permanent motor and planetary gears rotate a shaft that controls a hand valve mounted on the top of the container. The hand valve is normally closed, sealing the container. Valves within the container allow inlet flow but no reverse flow, thereby securing the sample. The motor current, motor running time, and shaft revolutions show on surface read-outs during a sampler run (Fig. $A-2$ ).

\begin{tabular}{|l|l|}
\hline \multicolumn{3}{|c|}{ Operating Specificat ions } \\
Temperature Rating $--300^{\circ} \mathrm{C}\left(572^{\circ} \mathrm{F}\right)$ \\
Fluid Pressure & $--15,000 \mathrm{ps}$ i \\
Length & $--89 \mathrm{in}$. \\
Diameter & $--5.0 \mathrm{in}$. \\
Weight & $--229 \mathrm{~b}_{3}$ \\
Sample Size & $--780 \mathrm{~cm}^{3}$
\end{tabular}

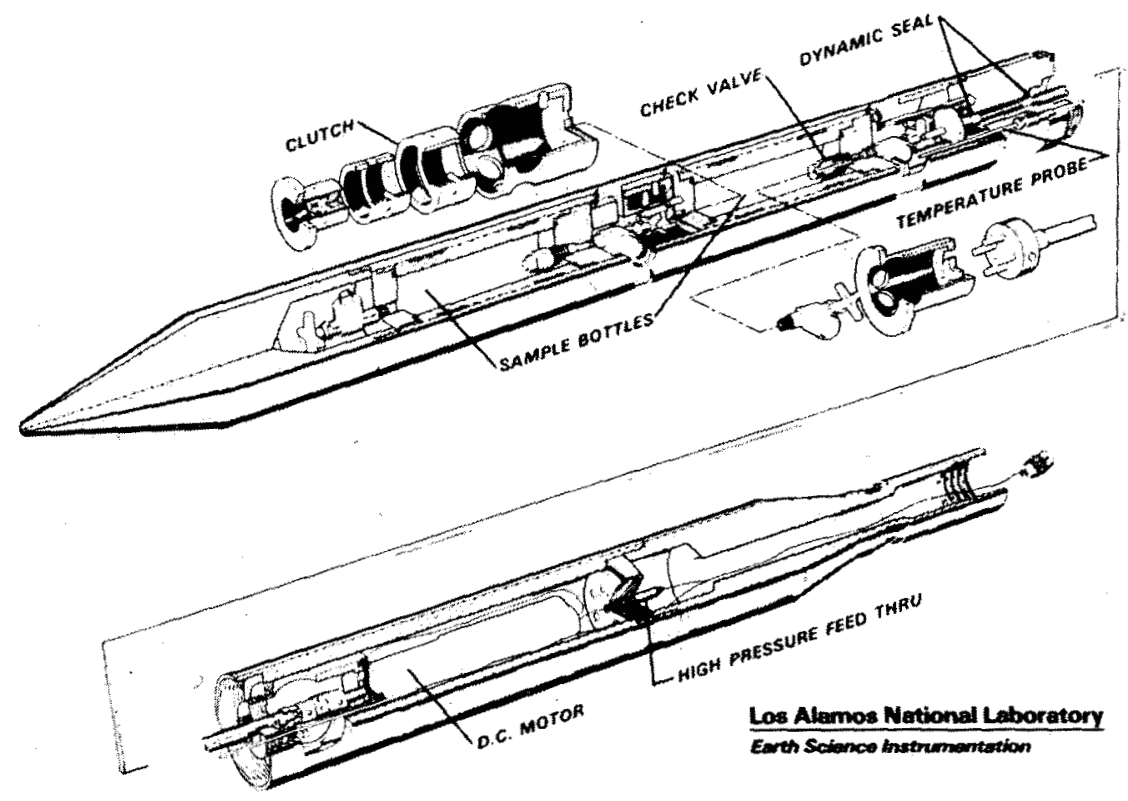

Fig. A-2.

Borehole fluid sampler. 
Temperature Probes

Borehole temperature surveys provide diagnostic measurements for geothermal reservoir characterization. The measurements are used to determine thermal gradient along the borehole, locate borehole fracture intersections, and calculate thermal drawdown and recovery rates of the circulating systems. The temperature probes give diagnostic data during drilling, cementing, pressurization, and hydraulic-fracturing operations. The sonde incorporates a high-temperature collar locator to tag casing signatures used to correct cabie depth.

The high-temperature probes, fabricated in various sizes, are wellbore survey tools that are readily fielded and allow on-line analys is of changing borehole conditions. All Los Alamos temperature sondes use a thin-walled, stainless steel thermistor probe as the sensor (Fig. A-4).

\begin{tabular}{|c|c|c|c|}
\hline $\begin{array}{l}\text { Temperature Rating } \\
\text { Fluid Pressure } \\
\text { Length } \\
\text { Diameter } \\
\text { Weight } \\
\text { No. of Conductors } \\
\text { Opt ions }\end{array}$ & $\begin{array}{l}\frac{\text { Operating Spe }}{\text { Standard }} \\
\frac{0^{\circ} \mathrm{C}\left(662^{\circ} \mathrm{F}\right)}{15,000 \mathrm{psi}} \\
73 \mathrm{in} . \\
2.625 \mathrm{in} . \\
84 \mathrm{lb} \\
4 \\
\text { Collar Locator }\end{array}$ & $\begin{array}{l}\frac{\text { ifications }}{\text { Slimline }} \\
\frac{\text { 350 }}{\circ 0^{\circ} \mathrm{C}\left(662^{\circ} \mathrm{F}\right)} \\
15,000 \mathrm{psi} \\
112 \mathrm{in.} \\
2.0 \mathrm{in.} \\
76 \mathrm{~b} \\
6 \\
\text { Collar Locator }\end{array}$ & $\begin{array}{l}\text { Heavy Duty* } \\
350^{\circ} \mathrm{C}\left(662^{\circ} \mathrm{F}\right) \\
15,000 \mathrm{psi}^{-} \\
117 \mathrm{in.} \\
2.0 \mathrm{in.} \\
230 \mathrm{lb} \\
4 \\
\text { Collar Locator }\end{array}$ \\
\hline
\end{tabular}

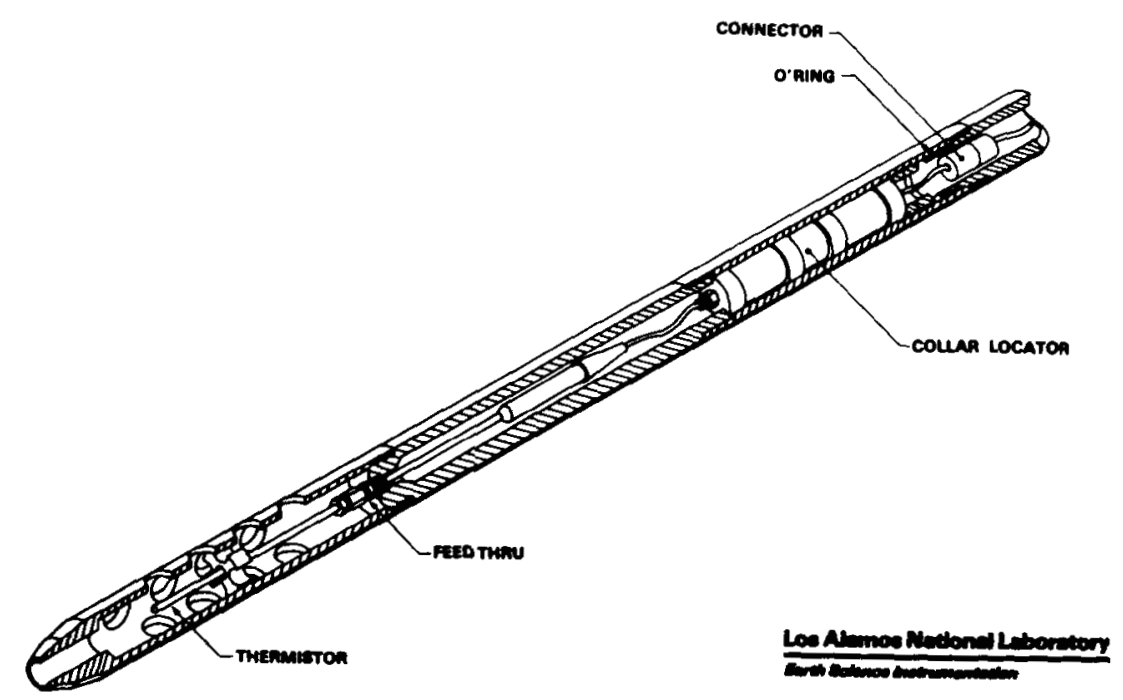

Fig. A-4.

Sl iml ine temperature/collar locator tool. 


\section{Cal iper Tool}

An independent multiarm caliper tool was designed to define the profile of geothermal boreholes such as those at Fenton Hill. Development began with the design and fabrication of a prototype 3-arm sonde, which can be modified to have six independent arms. The arms are evenly spaced circumferentially and are capable of measuring radi $i$ from 2-1/2 to 7 in. at a common depth. Arm length can be varied to measure hole diameters up to $30 \mathrm{in.}$ or can be designed for maximum sensitivity at given diameters. The arms are activated by a motor and can be extended or retracted on command from the surface. Should the sonde become jammed in the borehole, the lower link will buckle and permit the arms to collapse (Fig. A-5).

\begin{tabular}{|c|c|}
\hline \begin{tabular}{l}
\multicolumn{2}{r}{ Operating Spec: } \\
Temperature Rating - \\
Fluid Pressure \\
Length \\
Diameter \\
Weight \\
Radii
\end{tabular} & $\begin{array}{l}\text { ifications } \\
-300^{\circ} \mathrm{C}\left(572^{\circ} \mathrm{F}\right) \\
-15,000 \text { ps } \mathrm{i} \\
-112 \text { in. } \\
-3.0 \text { in. } \\
--154 \text { 1b } \\
=-8-14-2 \text { in. (Change } \\
\quad \text { Arm Length) }\end{array}$ \\
\hline
\end{tabular}

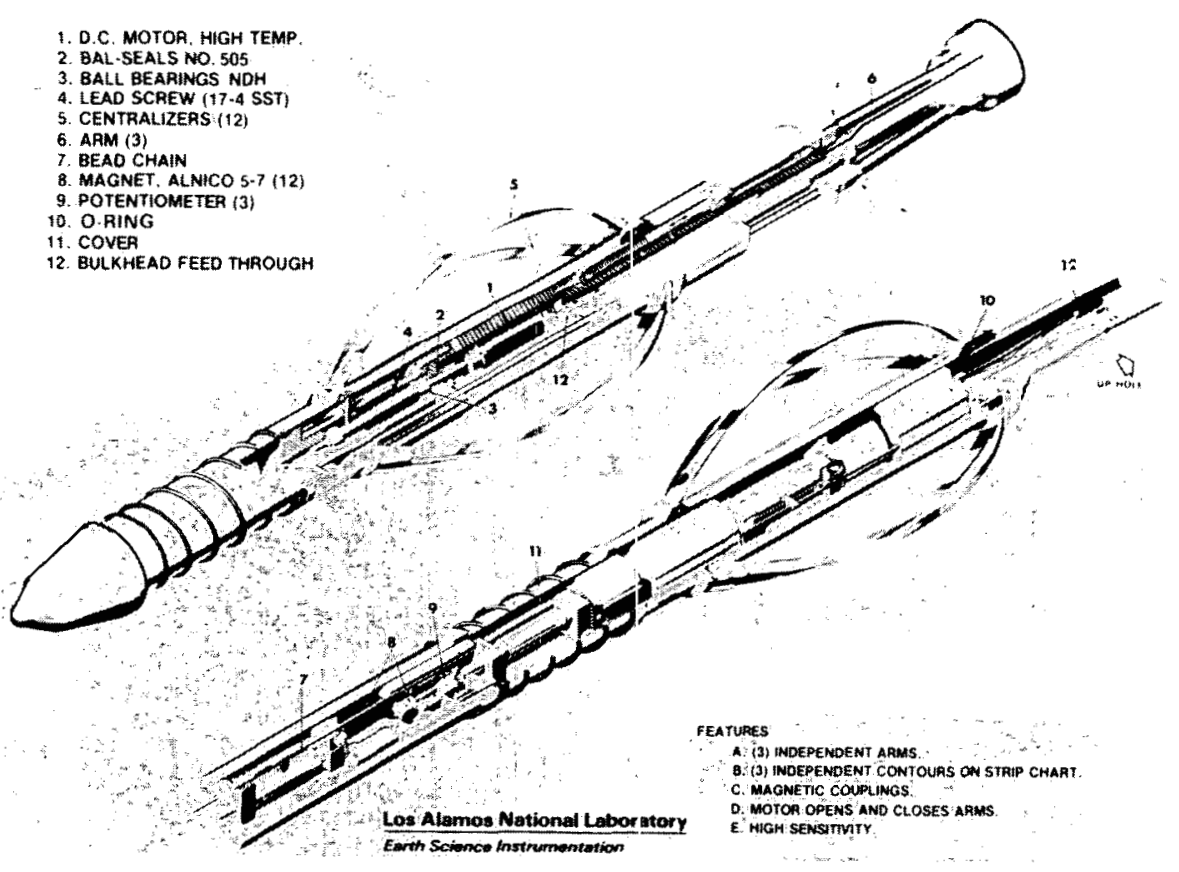

Fig. A-5.

Cal iper and contour tool. 
Downhole Injector and Gamma-Ray Detector

Radioactive tracers injected at specific locations in the borehole show fluid circulation in the fractured geothermal reservoir. Radioactive $\mathrm{Br}^{82}$ or other radioactive tracer is injected into the injection well with the injector system developed at Los Alamos. A gamma-ray detector is mounted in the same sonde as the injector. The gamma-ray detector is thermally protected in a dewar using a cerrobend heat sink. When the sonde is positioned in the borehole at a predetermined release location, a motor-propelled rod smashes the quartz ampoule that contains the tracer. The integral gamma-ray detector tracks the radioactive tracer as it leaves the injection well. A second gamma-ray detector measures the arrival of the tracer in the production well.

\begin{tabular}{|c|c|}
\hline \multicolumn{2}{|c|}{ Operating Specifications } \\
\hline $\begin{array}{l}\text { Temperature Rating } \\
\text { Fluid Pressure } \\
\text { Length with Injector } \\
\text { Length without Injector } \\
\text { Diameter } \\
\text { We ight with Injector } \\
\text { Weight without Injector }\end{array}$ & $\begin{array}{l}--300^{\circ} \mathrm{C}\left(572^{\circ} \mathrm{F}\right) \\
--15,000 \mathrm{ps} i \\
--121 \text { in. } \\
--95 \text { in. } \\
--3.25 \text { in. } \\
--175 \mathrm{ib} \\
--145 \mathrm{ib}\end{array}$ \\
\hline
\end{tabular}

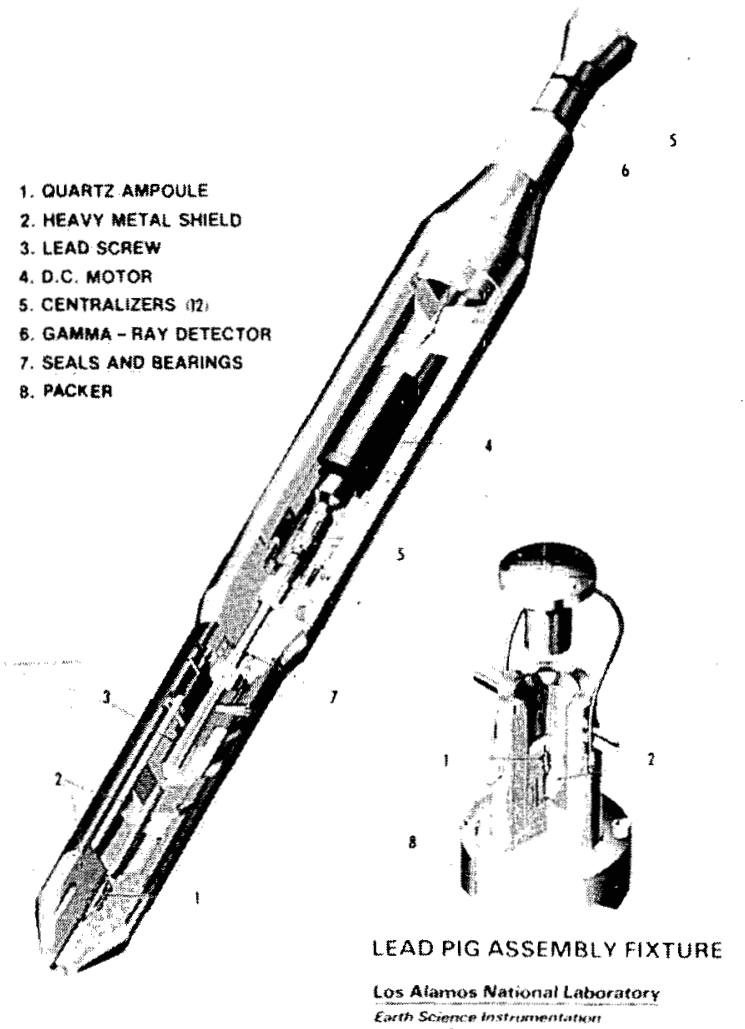

Downhole $\mathrm{Br}^{82}$ injector and garma-ray detector. 


\section{Fluid Velocity (Spinner) Probe}

The fluid velocity probe yields accurate data about complete fluid-flow patterns in a borehole. A typical borehole will have fractures in several zones. The fluid velocity, as measured by the sensor, can help characterize the manmade reservoir by determining the nature and location of the fractures, where and how much fluid leaves or enters the borehole, and the relative contribution of each fracture to the total reservoir. The Los Alamos instrument has improved resolution, repeatability, and sensitivity. The impeller size was increased, and the interface electronics was designed to provide better resolution and to increase the analog output from 10-mV to $10-V$ full scale. This tool can log the boreholes vertically in either direction (Fig. A-7).

With the information regarding flow rates at various positions in the borehole, combined with data from the caliper tool, we can ascertain the location of hydraulic fractures and volumetric contributions from each fracture.

\begin{tabular}{|c|c|c|}
\hline \multicolumn{3}{|c|}{ Operating Specifications } \\
\hline & Standard & sl iml ine \\
\hline Temperature Rating & $300^{\circ} \mathrm{C}\left(572^{\circ} \mathrm{F}\right)$ & $300^{\circ} \mathrm{C}\left(572^{\circ} \mathrm{F}\right)$ \\
\hline $\begin{array}{l}\text { Fluid Pressure } \\
\text { Length }\end{array}$ & $15,000 \mathrm{psi}$ & 15,000 ps $i$ \\
\hline Diameter & $100 \mathrm{in}$. & 101 in. \\
\hline Weight & $2001 \mathrm{~b}$ & $70 \mathrm{lb}$ \\
\hline Opt ion & Temperature & Temperature \\
\hline
\end{tabular}

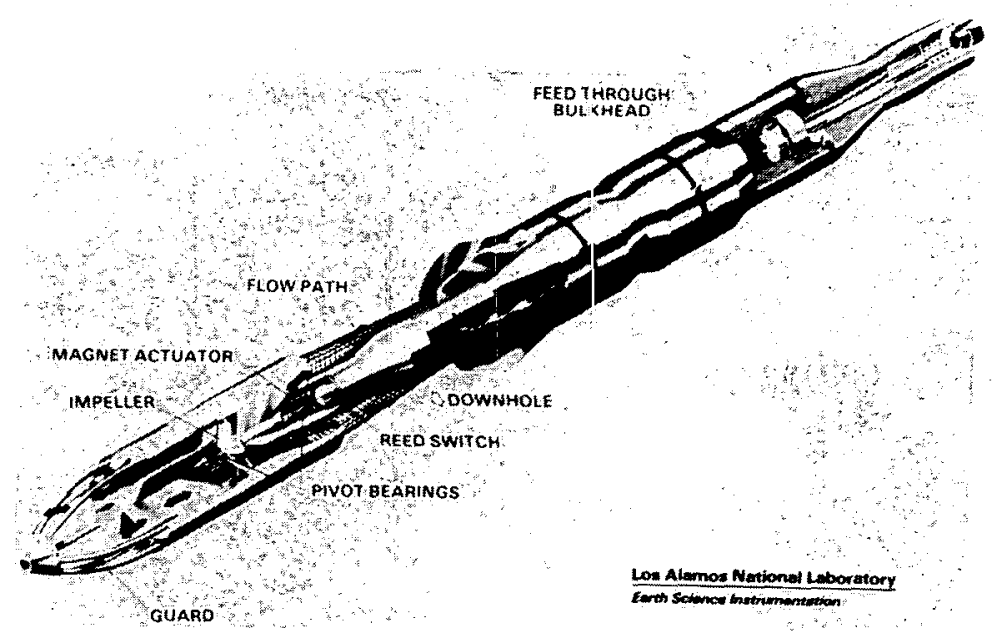

Fig. A-7.

Fluid velocity (spinner) probe. 
Geophone Acoust ic Detector

The triaxial geophone detector incorporates a downhole multiplex system to enhance signal-to-noise and increase data frequency transmission. The multiplex electronics, housed in a thermal protection system, also allows monitoring of additional pertinent data such as the internal dewar temperature, sonde orientation, and power supply voltages. Borehole slant angle is measured and referenced to previous wellbore surveys to provide geophone orientation (Fig. A-8).

\begin{tabular}{|lll|}
\hline \multicolumn{3}{c|}{ Operating Specifications } \\
Temperature Rating & $\frac{\text { Standard }}{275^{\circ} \mathrm{C}\left(527^{\circ} \mathrm{F}\right)}$ & $\frac{275^{\circ} \mathrm{Cm}\left(527^{\circ} \mathrm{F}\right)}{}$ \\
Fluid Pressure & $15,000 \mathrm{psi}$ & $15,000 \mathrm{psi}$ \\
Length & $68 \mathrm{in}$. & $152 \mathrm{in.}$ \\
Diameter & $5.5 \mathrm{in}$. & $3.25 \mathrm{in}$. \\
Weight & $160 \mathrm{ib}$ & $52 \mathrm{~b}$ \\
Natural Frequency & $30 \mathrm{~Hz}$ & $30 \mathrm{~Hz}$ \\
\hline
\end{tabular}

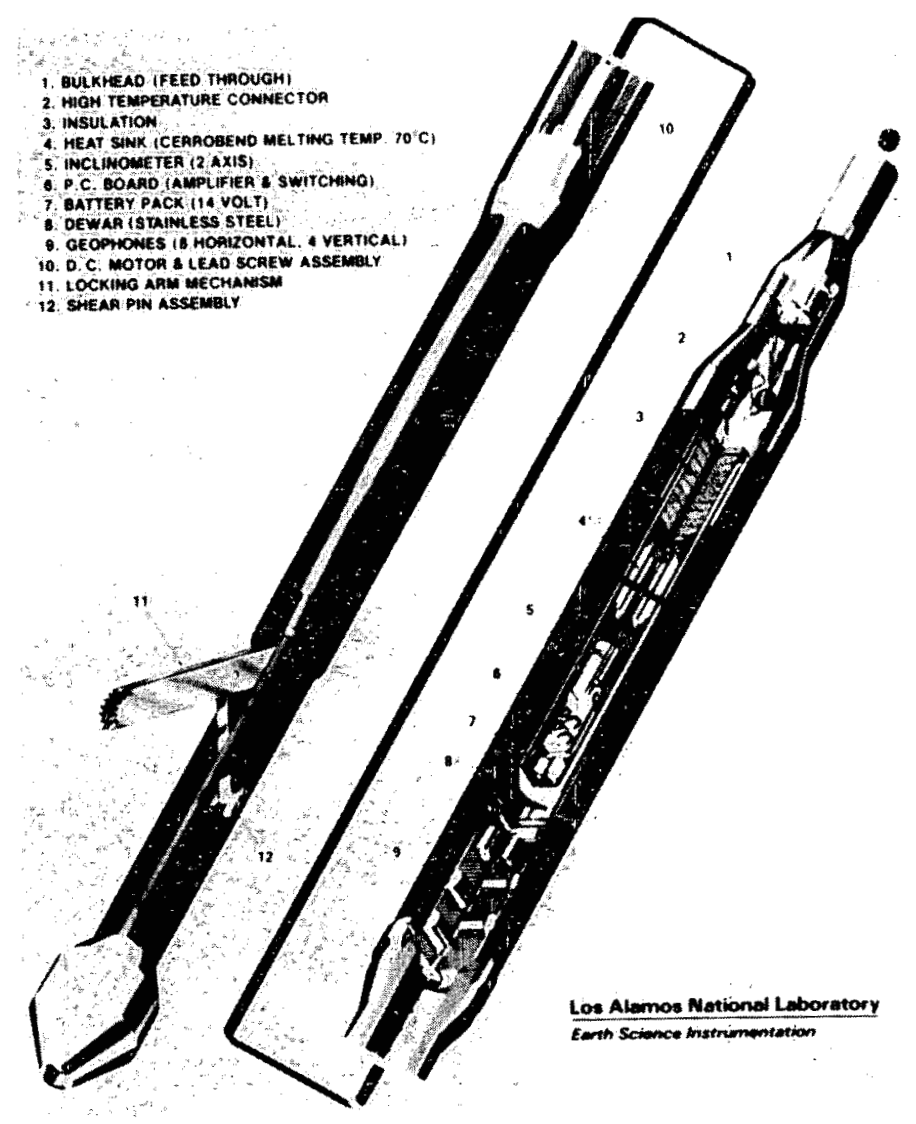

Fig. A-8.

Geophone acoust ic detector. 


\section{Crosswell Acoustic Transceiver - Transmitter}

The transmitter generates an acoustic source by discharging a large hightemperature capacitor through an SCR firing circuit to two magnetostrictive devices (scrolls). A digital timing circuit controls the source repetition rate. The scrolls are housed in an oil-filled cavity, and source coupling takes place through a TFE Teflon window. Pressure inside the window is balanced using a movable piston assembly. The transmitter is capable of generating acoustic signals at a power level of $3 \mathrm{~J}$ (Fig. A-9).

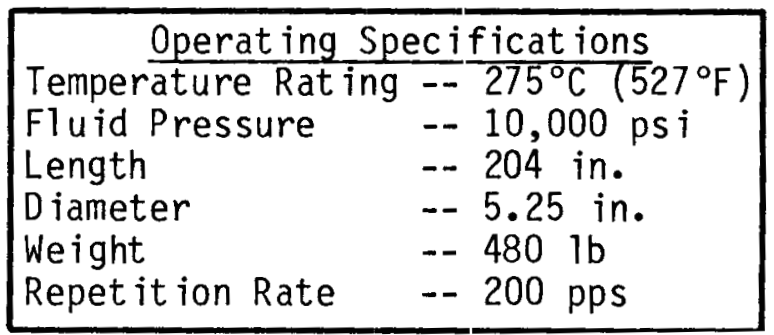

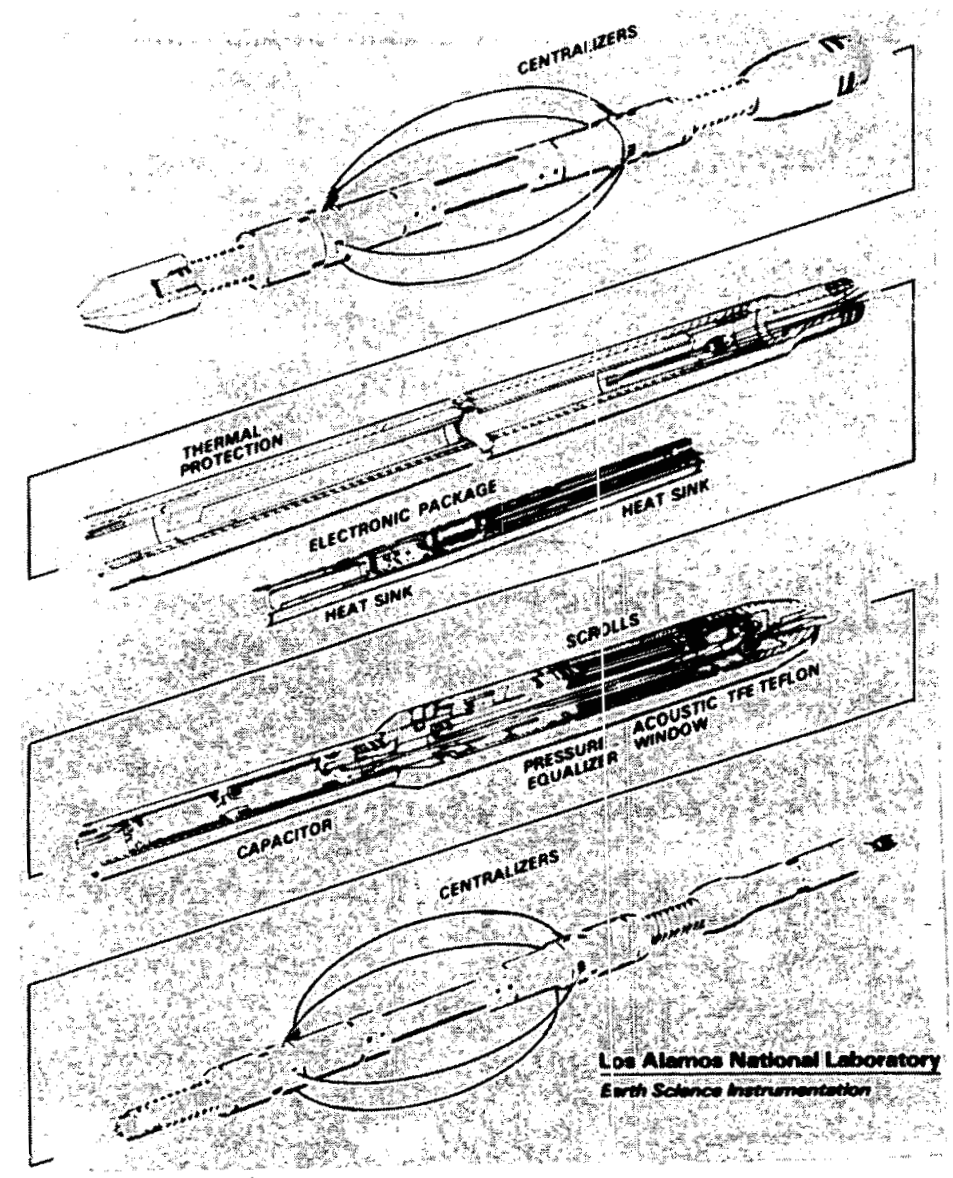

Fig. A-9.

Acoustic transceiver transmitter. 
Crosswell Acoustic Transceiver - Receiver

The receiving unit uses a piezoelectric crystal, which is cylindrical and is segmented into six sections. The crystal is also housed in an oil-filled cavity inside the TFE Teflon window, using a pressure balance system identical to the transmitter. The crystal output is conditioned by an Endevco charge amplifier to convert the high-impedance source charge to a low-impedance voltage output. The output signal is processed through an automatic gain system and is frequency modulated for transmission up the armored logging cable. Receiver electronics is thermally protected in a dewar and heat sink assembly (Fig. A-10).

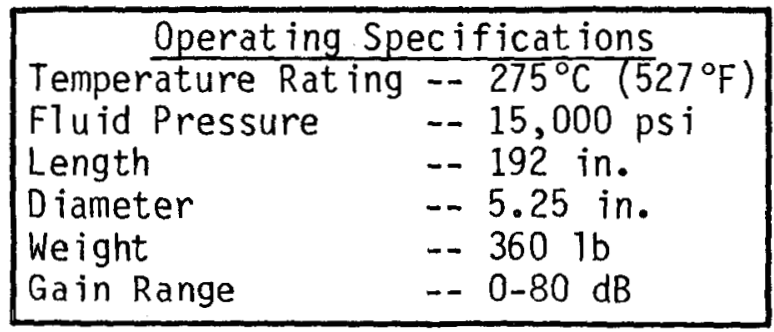

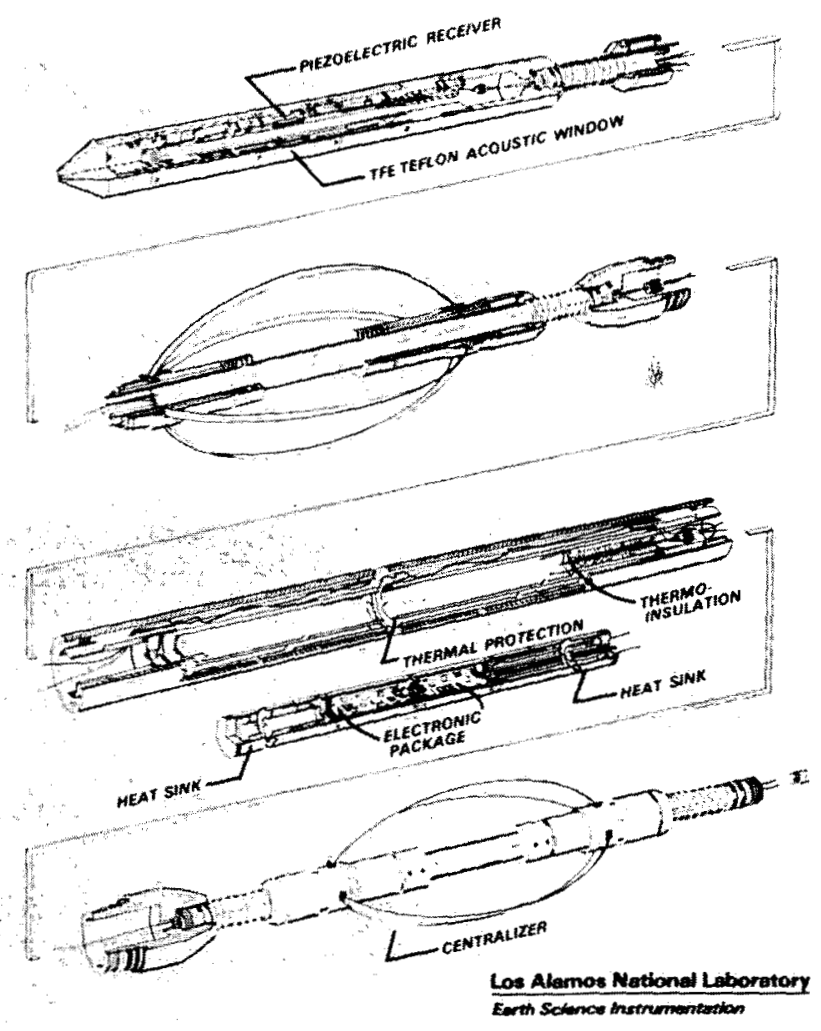

Fig. A-10.

Acoustic transceiver receiver. 


\section{Borehole Acoust ic Televiewer}

The borehole acoustic televiewer use's two piezoelectric crystals mounted $180^{\circ}$ apart on a rotating block. Either the $1.3 \mathrm{MHz}$ or the $650 \mathrm{kHz}$ crystal may be selected as the working frequency by means of the uphole control unit. An ac synchronous motor rotates the crystals in a silicon oil-filled cavity at $360 \mathrm{rpm}$. The TFE Teflon windows separate the silicon $0 i 1$ and the borehole fluids. A floating piston assembly preserves the pressure balance. Data are processed downhole by an Intel $8085 \mathrm{microprocessor}$ and then transmitted to the surface control unit by PCM encoded wavetrain. Collected data are stored on a 1/4- in. magnetic tape for off-line data analys is (Fig. A-11).

\begin{tabular}{|l|l|}
\hline \multicolumn{2}{|c|}{ Operat ing Specificat ions } \\
Temperature Rating -- & $275^{\circ} \mathrm{C}\left(527^{\circ} \mathrm{F}\right)$ \\
Fluid Pressure & $--12,000 \mathrm{ps} i$ \\
Length & $--14 \mathrm{ft}$ \\
Diameter & $--3.375 \mathrm{in}$. \\
Weight & $--225 \mathrm{lb}$ \\
Logging Rate & $--10 \mathrm{ft} / \mathrm{min}$ \\
\hline
\end{tabular}

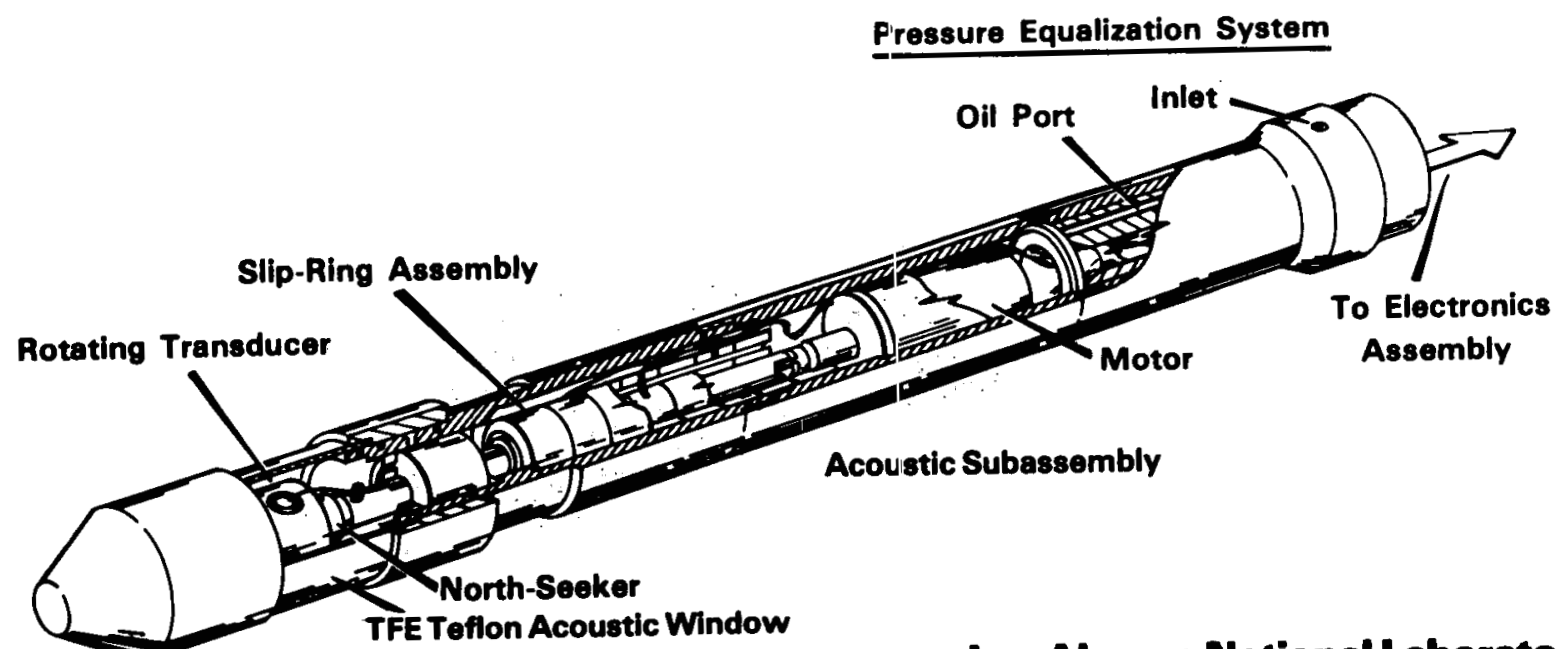

Los Alamos National Laboratory

Earth Sclonco Instrumentation

Fig. A-11.

Borehole acoust ic televiewer (BAT). 


\section{Acoust ic Source Detonator}

The multiple-fire detonator sonde can sequentialiy fire up to 12 detonators that simulate an acoustic signal from a known location in one of the wellbores at Fenton $\mathrm{Hill}$. The signal is detected by the geophone packages deployed in the adjacent boreholes and is used to calibrate the geophone array in each sonde. The downhole firing system consists of the firing module, detonator rack, and high-temperature detonators. The detonator rack has three levels, each of which accommodates four exploding-foil detonators designed for high-temperature and high fluid pressures. These detonators are inherently safe from accidental detonation during transit and handling (Fig. A-12).

\begin{tabular}{|l|l|}
\hline \multicolumn{3}{c}{ Operat ing Spec ificat ions } \\
Temperature Rat ing $--250^{\circ} \mathrm{C}\left(482^{\circ} \mathrm{F}\right)$ \\
Fluid Pressure & $--10,000 \mathrm{ps} \mathrm{i}$ \\
Length & $--152 \mathrm{in}$. \\
Diameter & $--5.75 \mathrm{in}$. \\
Weight & $--520 \mathrm{~b}$ \\
Detonator Size & $--1.33 \mathrm{~g}$
\end{tabular}

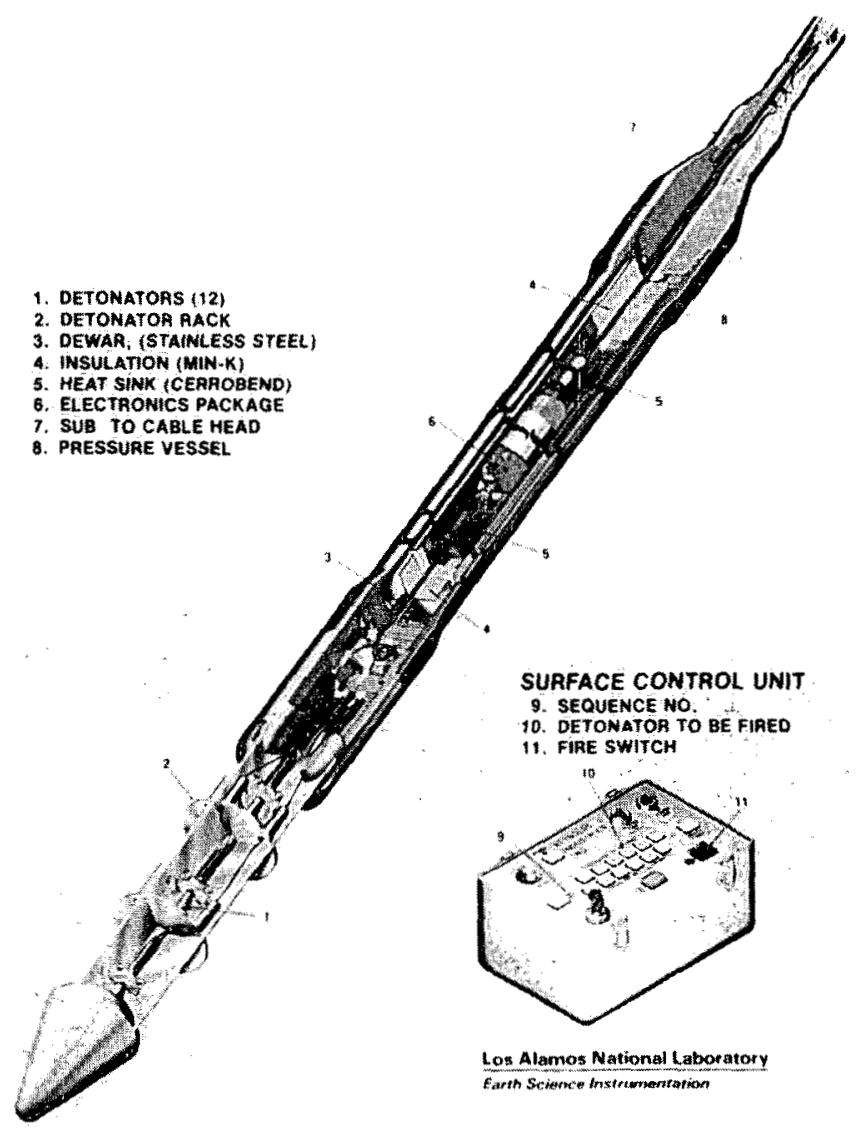

Fig. A-12.

Acoust ic source detonator. 
Sliml ine Detonator Tool and String Shot

The sliml ine detonator tool is designed to run in drill pipe or frac-string. It can fire two detonators and, except for size, is based upon the multishot detonator acoustic source. This tool has been modified by adding a front-end carrier with a larger explosive charge, and now the tool can be used for a high-temperature string shot or backoff (Fig. A-13).

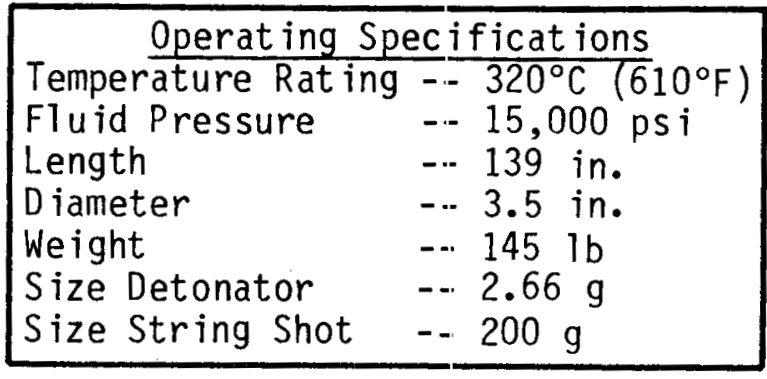

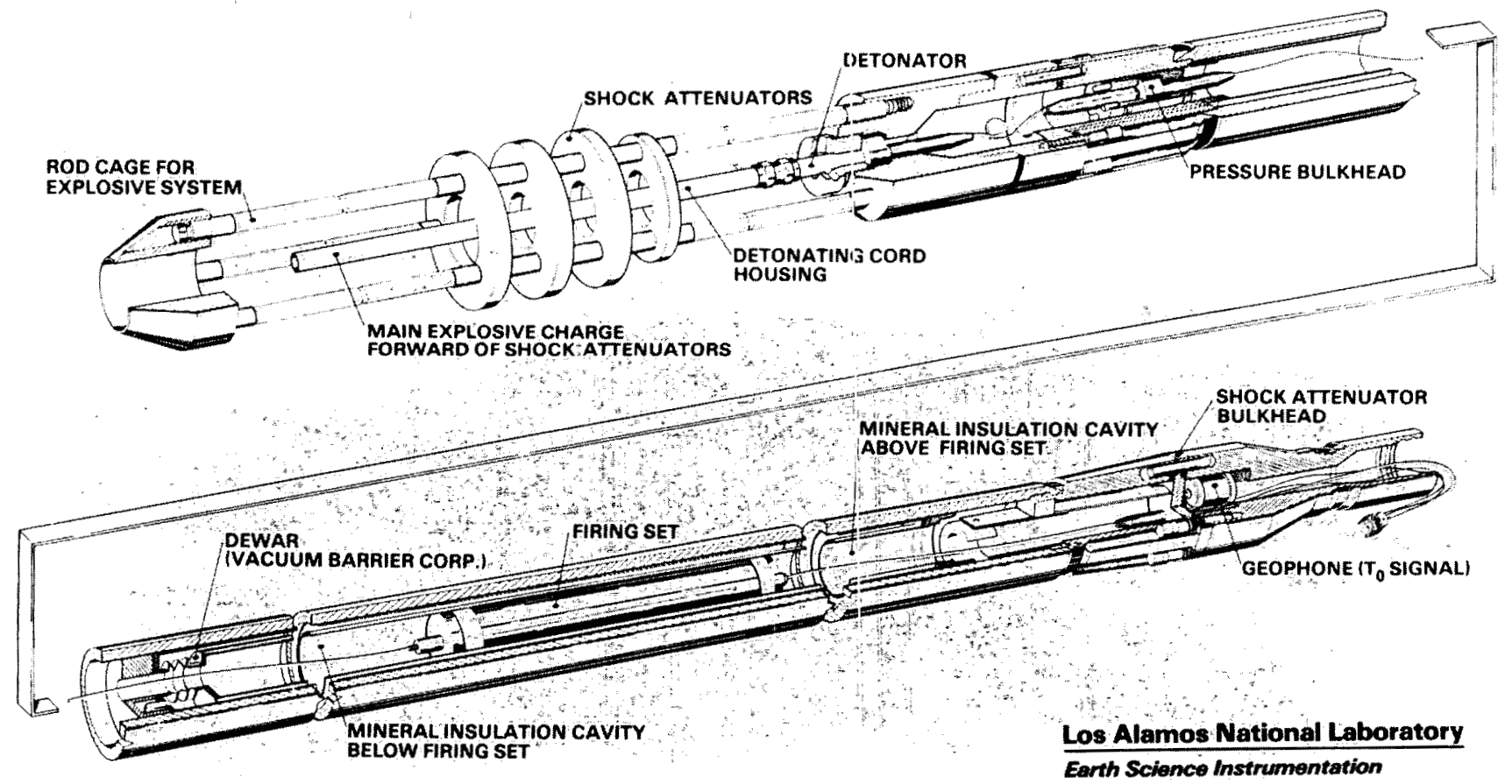

Fig. A-13.

String shot/detonator explosive tool. 


\section{Drill Pipe Severing Device}

The drill pipe severing device uses a shaped lens to provide an explosive cutting tool that leaves a clean circumferential edge where it cuts the drill pipe or casing. The downhole firing unit and high-temperature detonator are the same as those used in the string shot and multiple fire detonator tool. The lens and shaped charge must be designed for each size pipe or casing in the wellbore (Fig. A-14).

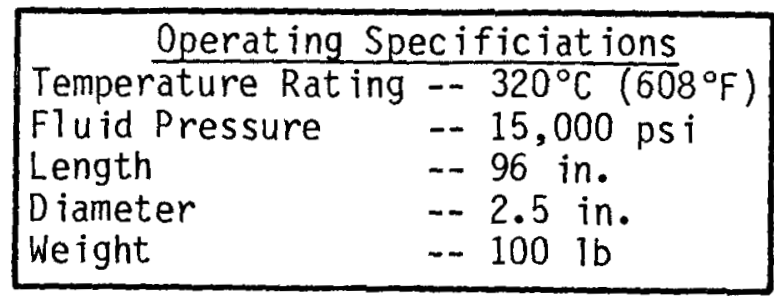

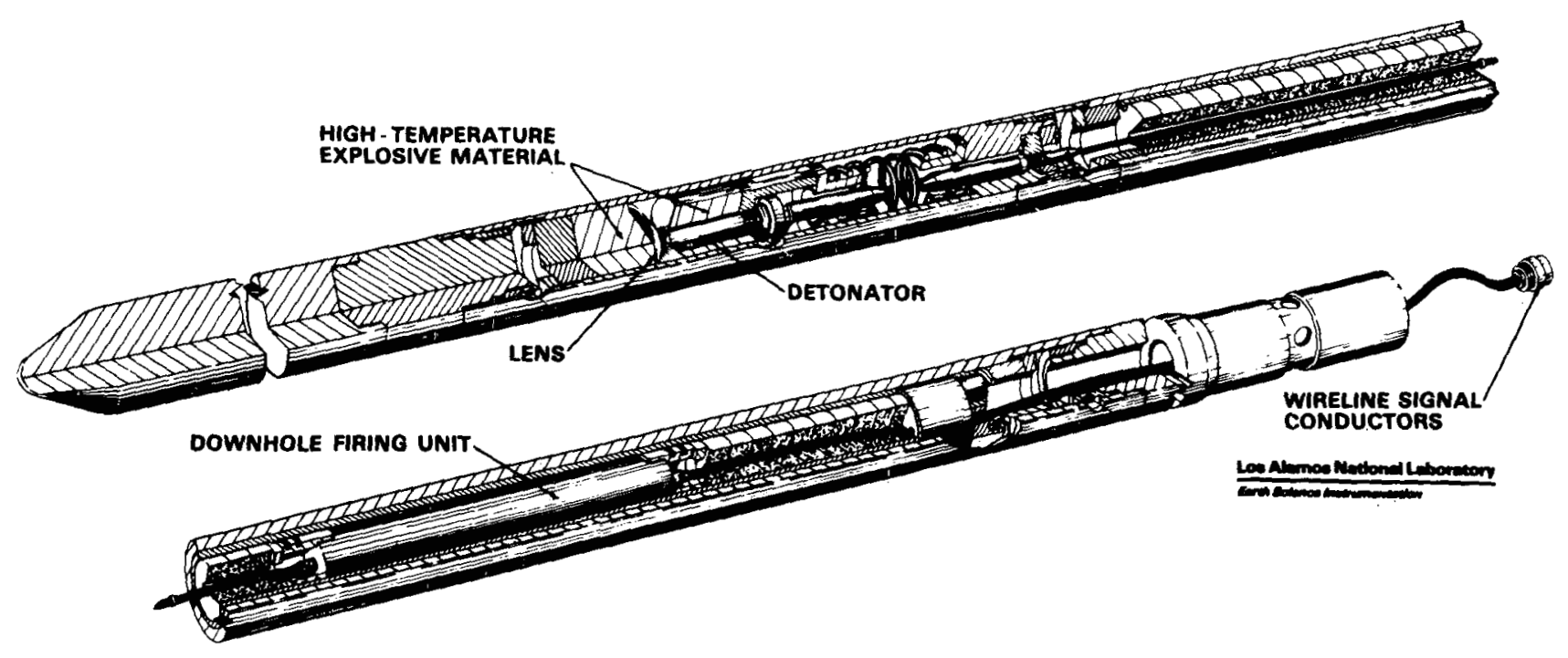

Fig. A-14.

Drill pipe severing device. 


\section{Explosive Fracture Initiation Tool}

The explosive fracture initiation tool deploys and detonates a small explosive charge at a preselected position in the open borehole section of a geothermal wellbore. Detonation of the shaped charge can initiate fractures in the selected zone. Then hydraulic pressurization extends the fractures into the formation. The downhole firing unit, detonators, and explosives are like those used in all the explosive tools (Fig. A-15).

\begin{tabular}{|l|l|}
\hline \multicolumn{2}{|c|}{ Operating Specificat ions } \\
Temperature Rating $-320^{\circ} \mathrm{C}\left(610^{\circ} \mathrm{F}\right)$ \\
Fluid Pressure & $--10,000 \mathrm{ps}$ \\
Length & --225 in. \\
Diameter & --3.25 in. \\
Weight & $--3101 \mathrm{~b}$ \\
\hline
\end{tabular}

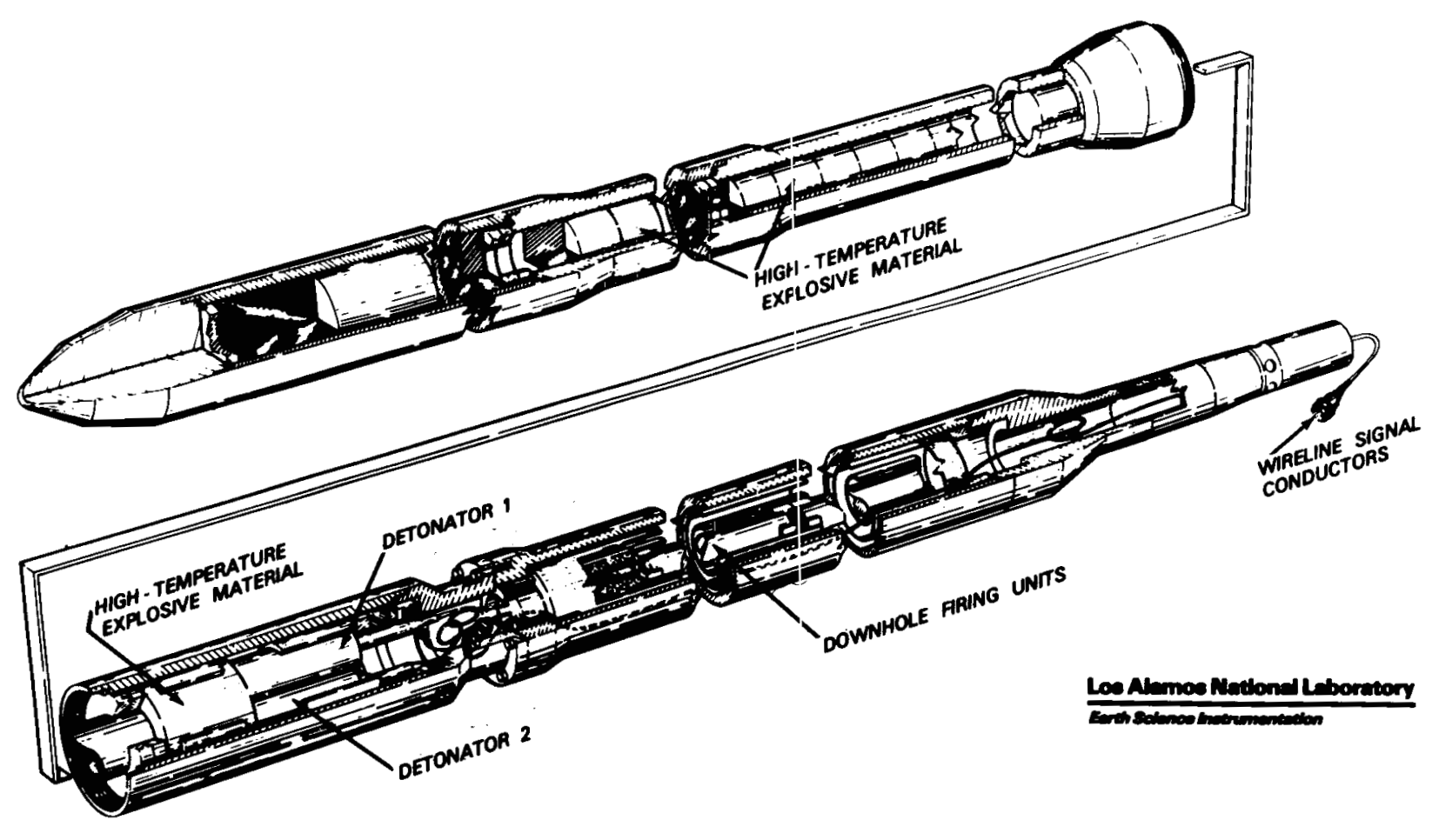

Fig. A-15.

Explosive fracture initiation device. 


\section{Explosive Sidetracking Tool}

This tool uses an explosive-shaped charge to rubblize a bell-shaped cavity in the borehole to provide a sidetracking ledge in the hard granitic rock. This ledge allows the drill bit with bent subassembly to sidetrack from the low side of the borehole (Fig. A-16).

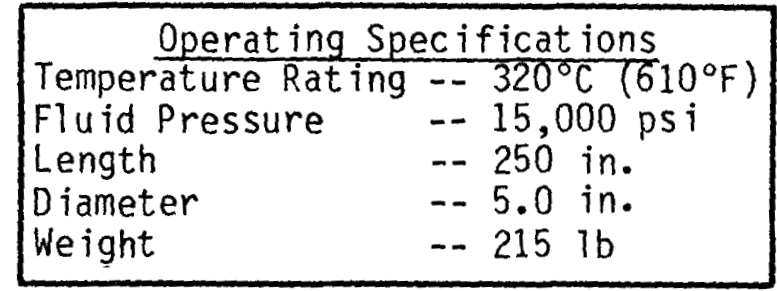

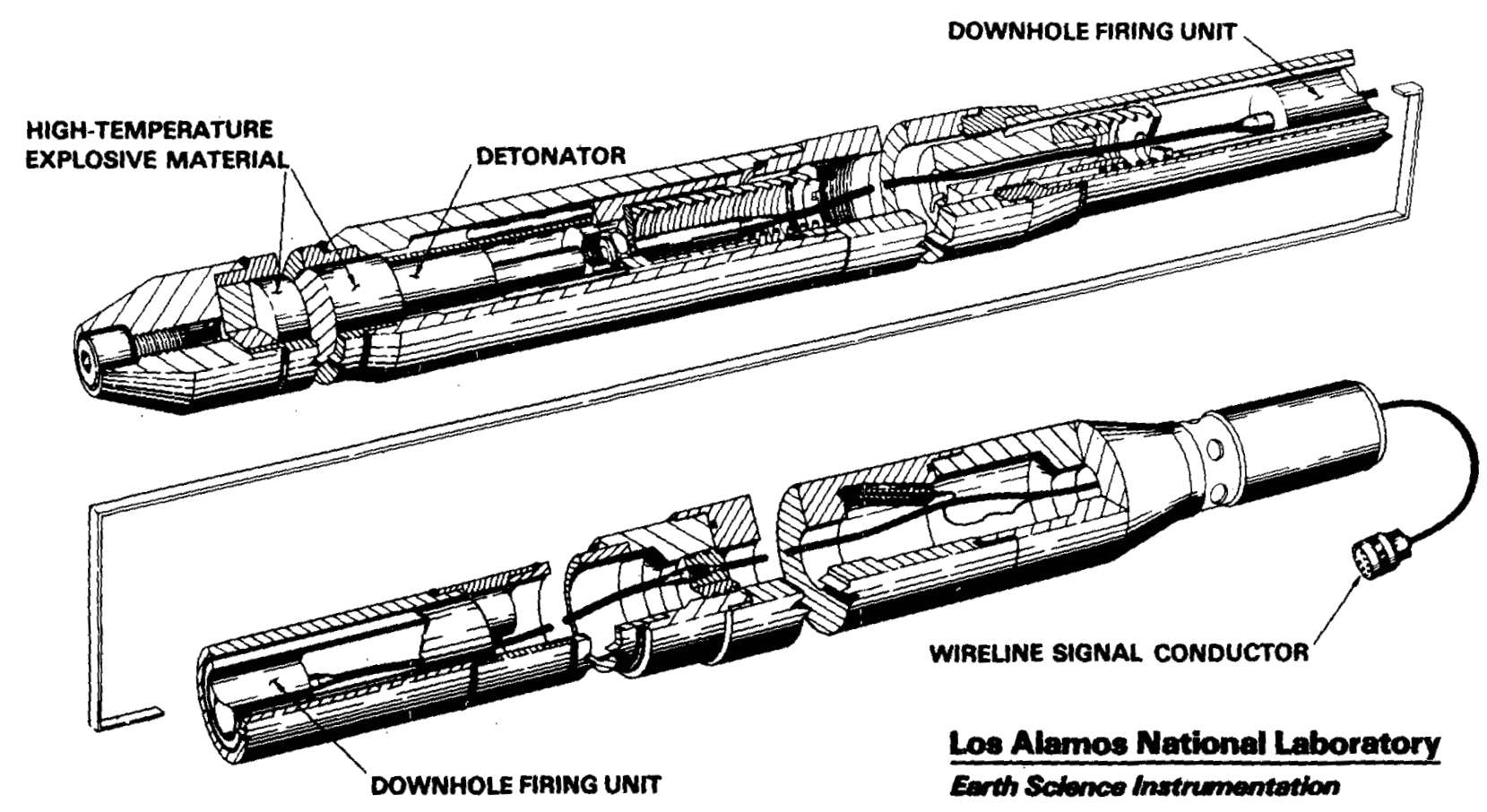

Fig. A-16.

Explosive sidetracking device. 